\title{
Notes for a New Guide to Keynes (I): Wages, Aggregate Demand, and Employment \\ $*$
}

\author{
Jordi Galí ${ }^{\dagger}$
}

September 28, 2012

\begin{abstract}
I revisit the General Theory's discussion of the role of wages in employment determination through the lens of the New Keynesian model. The analysis points to the key role played by the monetary policy rule in shaping the link between wages and employment, and in determining the welfare impact of enhanced wage flexibility. I show that the latter is not always welfare improving.
\end{abstract}

JEL Classification: E32.

Keywords: wage flexibility, monetary policy rules, employment stability.

${ }^{*}$ Delivered as the Presidential Address to the 27th Annual Congress of the European Economic Association, held in Málaga, August 27-31, 2012. I thanks participants at the EEA Congress, the EABCN Workshop, and the CREI Macro Lunch for useful comments and suggestions. I acknowledge financial support from the Ministerio de Ciencia e Innovación (ECO2011-23188).

†CREI, Universitat Pompeu Fabra and Barcelona GSE. 


\section{Introduction}

Last year marked the 75th anniversary of the publication of John Maynard Keynes's landmark work The General Theory of Employment, Interest, and Money (Keynes (1936)). Together with Adam Smith's Wealth of Nations and Karl Marx's Capital, the General Theory is one of the most influential books ever written in economics and, arguably, in any field. Keynes's work triggered a paradigm change with ripple effects that have been echoed to this day.

Despite its notoriety, the General Theory is generally viewed, even by professional economists, as an unfriendly read. ${ }^{1}$ That opacity may account for the several books and articles that were written after its publication, largely aimed at economists and students of economics, and whose purpose was to serve as a "tutorial guide" to Keynes's magnum opus. Among the best known of such publications is Alvin Hansen's "A Guide to Keynes" (Hansen (1953)), which has inspired the title of the present lecture. ${ }^{2}$

The motivation behind my proposed "new guide to Keynes" is not to offer yet another reader's companion to the General Theory. Instead, my objective is to discuss and reflect on the connections between Keynes's original work and so-called New Keynesian economics, the dominant paradigm in macroeconomics over the past two decades. To be more concrete, my goal is to revisit some aspects of Keynes's General Theory through the lens of New Keynesian economics, i.e. using the tools and language of the latter. The ultimate aim of a project of this nature is to help understand better both Keynes and New Keynesian economics, and, hopefully, to draw lessons from both that we can apply to our current economic problems.

The themes and topics covered by the General Theory are large in number and broad in scope. An exhaustive coverage would require more time and space than is suitable for a lecture of this nature. So I have chosen to restrict its focus to a narrow theme: the role of wages as a determinant of employment and, in particular, the welfare and stability gains that may result from greater wage flexibility.

The motivation for choosing this particular topic is twofold. Firstly, Keynes's treatment of this subject, focusing on the contrast between his

\footnotetext{
${ }^{1}$ One possible reason for this was Keynes's reluctance to rely on mathematics to support or and/or clarify his verbal arguments.

${ }^{2}$ John Hicks's "Mr. Keynes and the Classics; a Suggested Interpretation," (Hicks (1937)) is another such work.
} 
view and that of classical economics, as well as their differential policy implications, arguably constitutes the core of the General Theory. Secondly, the belief in the virtues of wage flexibility and the desirability of wage moderation in the face of high unemployment seem to have permeated fully current policy thinking. The Great Recession and the "crisis of the euro" have only reinforced those views, which are often conveyed by messages that have attained the status of mantras in policy circles. The following quotation, drawn from a recent ECB Monthly Bulletin, exemplifies that perspective:

"...Further significant reductions in unit labor costs and excess profit margins are particularly urgent, especially in countries where unemployment is very high. To achieve this, first, flexibility in the wage determination process has to be strengthened, for example, where relevant, by relaxing employment protection legislation, abolishing wage indexation schemes, lowering minimum wages and permitting wage bargaining at the firm level..." (ECB, Monthly Bulletin, August 2012) ${ }^{3}$

The remainder of the paper is organized as follows. Section 2 contrasts the classical and Keynesian views of employment and wage determination, as described in the General Theory. In section 3 I describes the main ingredients of the New Keynesian model used in subsequent sections, emphasizing differences and similarities with the framework underlying Keynes's General Theory. In section 4 I discuss two issues for which New Keynesian models offer a different perspective from that in Keynes's original work: the cyclicality of wages and the impact of technology shocks on employment. Section 5 revisits the case for wage flexibility in the context of the New Keynesian model. Section 6 raises and discusses a number of caveats in the previous analysis. Section 7 concludes.

\section{Keynes vs the Classics in the General The- ory}

Next I summarize the key differences between the Classical and Keynesian views on the determinants of employment and their implications regarding

\footnotetext{
${ }^{3}$ Emphasis added.
} 
possible cures for the unemployment problem, as described by Keynes himself in Book I of the General Theory. Throughout I rely on a simple labor market diagram to convey the main ideas.

\subsection{The Classical Theory of Employment}

A first key element in the classical theory of employment is given by a labor demand schedule. As shown in Figure 1, that schedule determines the amount of labor $n$ that firms want to employ given the prevailing real wage, $w-p$ (both variable expressed in logs). It follows from profit maximization by perfectly competitive (i.e. price and wage taking) firms, given the available technology. The corresponding optimality condition requires that the firm hires labor up to the point where its marginal product equals the real wage. Accordingly, the labor demand schedule corresponds to the the marginal product of labor, which is assumed to be decreasing. Note that under that view, the causality runs from wages to the employment, with the latter being determined without any consideration of the demand for goods, which firms perceive as perfectly elastic at the prevailing equilibrium price. In other words, firms view themselves as facing no demand constraints.

A labor supply schedule, depicted in Figure 2, constitutes the second key element in the classical framework. It determines the size of the labor force, $l$, i.e. the number of individuals willing to work given current labor market conditions. Formally, it can be derived by aggregating the optimal labor market participation decisions of wage-taking individuals. The labor force (or labor supply) is made up of all the individuals whose work disutility (or opportunity cost), expressed in terms of consumption goods, is no greater than the real wage. It is thus increasing in the latter, as shown in Figure 2.

The corresponding (Walrasian) equilibrium assumes that the wage adjust so that both equations -labor demand and labor supply- are satisfied simultaneously, as illustrated in Figure 3. How that adjustment is brought about is left unexplained, but one can easily come up with stories to motivate it. The fact that the economy is "on the labor supply curve" implies that individuals do not face any constraints or rationing of any sort when supplying their labor services. Accordingly, involuntary unemployment, $u \equiv l-n$, does not exist in such an equilibrium.

As pointed out by Keynes unemployment will emerge in a classical environment only if, due to the effects of collective bargaining or legal or institutional constraints, the prevailing wage lies above its Walrasian level, as 
illustrated in Figure 4. Employment is then determined by labor demand, and falls short of the corresponding labor supply. Accordingly, a fraction of individuals will be jobless despite their desire to work, i.e. involuntary unemployment will emerge.

In the previous environment, the "natural" relief to the unemployment problem would come from a downward adjustment in the real wage, possibly as a result of underbidding by the unemployed themselves. This is illustrated in Figure 5. If there are legal or institutional constraints that prevent that adjustment, employment can still be raised (and unemployment reduced) by means of an employment subsidy, which lowers the net compensation per worker effectively paid by the firm, and whose effect is to shift the labor demand schedule to the right, as illustrated in Figure 6.

\subsection{The Keynesian Theory of Employment}

Keynes's fundamental objection to the classical theory of employment lies in the latter's assumption that employment is determined by the real wage, without regard to aggregate demand conditions in the goods market. Instead, he turns the classical logic upside down, by viewing the real wage as being determined by employment, not the other way around.

The logic of the Keynesian theory of employment can be summarized as follows. Employment is determined by the quantity of output that firms want to produce, given the existing technology. In turn, desired output is a function of aggregate demand (for goods). This is illustrated in Figure 7, which displays labor demand as a vertical schedule, independent of the wage.

In this context, firms are viewed as monopolistic competitors in the goods market, facing a downward sloping demand for their (differentiated) goods. They price the latter according to a simple markup rule:

$$
p_{t}=\mu^{p}+\left(w_{t}-m p n_{t}\right)
$$

where $p_{t}$ denotes the $(\log )$ price, $w_{t}$.is the $(\log )$ nominal wage, $m p n_{t}$ is the (log) marginal product of labor, and $\mu^{p}$ denotes the desired (constant) price markup over marginal cost, $w_{t}-m p n_{t}$. Rearranging terms one can derive the implied wage schedule:

$$
w_{t}-p_{t}=m p n_{t}-\mu^{p}
$$

The latter schedule is represented in Figure 8 by a downward sloping line, capturing the assumption of decreasing returns to labor. Most impor- 
tantly, and as emphasized by the direction of the arrows, the Keynesian wage schedule should be interpreted as determining the real wage as a function of employment, given the state of technology. This is in stark contrast with the classical model, in which the real wage determines employment (with the latter determining output). Note also that under the Keynesian view, it is no longer true that the real wage can be determined freely through the bargaining between workers and their employers: any adjustment in the nominal wage would lead to a one-for-one change in the price, leaving the real wage unchanged. ${ }^{4}$ As a result, involuntary unemployment may emerge in equilibrium, as illustrated in Figure 9, with no "automatic" force guaranteeing that full employment be restored. Note that under this perspective a cut in nominal wages which is not accompanied by an expansion in aggregate demand will leave output, employment and the real wage unchanged, and will have no impact on unemployment. Similarly, an employment subsidy or a reduction in payroll taxes will leave employment unchanged, unless it is accompanied by an expansion of aggregate demand. ${ }^{5}$

As emphasized by Keynes, and as illustrated in Figure 10, the only solution to the unemployment problem in that environment lies in an expansion of aggregate demand, possibly brought about by a reduction in interest rates and/or an expansionary fiscal policy.

I have summarized above the fundamental differences between the classical and Keynesian views of employment determination and their implications regarding the possible role of wage flexibility as a cure to the unemployment problem, as exposited in Book I of the General Theory. In the remainder of the paper I revisit the key issues of contention using the New Keynesian model as a reference framework. I start by describing the main ingredients of that model.

\footnotetext{
${ }^{4}$ As Keynes emphasized, the previous statement applies to the economy as a whole, when it can be treated as a closed system. A change in the nominal wage restricted to one firm or one sector will trigger a change in its relative price and hence its employment and the corresponding product wage.

${ }^{5}$ Note that unemployment would be expected to rise in response to that policy, due to the higher participation induced by the increase in the wage accruing to workers (which will fully absorb the reduction in labor taxes if firms keep markups unchanged).
} 


\section{The Standard New Keynesian Model: Key Ingredients}

In the remainder of the paper I use a version of the standard New Keynesian model with sticky prices and sticky wages, as originally developed by Erceg, Henderson and Levin (2000). Only some of the model's key ingredients will be reviewed here, so I refer the interested reader to the expositions (with detailed derivations) that can be found in the literature. ${ }^{6}$

\subsection{Households/Preferences}

The economy is inhabited by a large number of identical households. Each household is made up of a continuum of members with measure one. Household preferences are given by

$$
E_{0} \sum_{t=0}^{\infty} \beta^{t} U\left(C_{t}, N_{t} ; X_{t}\right)
$$

where $C_{t}$ is a consumption bundle (which in turn is a CES function of the quantities consumed of the different types of goods), $N_{t}$ denotes the fraction of household members who are employed, and $X_{t} \equiv \exp \left\{x_{t}\right\}$.is a stochastic preference parameter (common to all households) which evolves according to the exogenous $A R(1)$ process:

$$
x_{t}=\rho_{x} x_{t-1}+\varepsilon_{t}^{x}
$$

Period utility $U$ is assumed to take the form

$$
U(C, N ; X)=\left(\log C-\frac{N^{1+\varphi}}{1+\varphi}\right) X
$$

Each household is specialized in the provision of some differentiated labor service, for which firms generate an isoelastic demand. Each period only a fraction $1-\theta_{w}$ of households, drawn randomly from the population, reoptimize their nominal wage in a way consistent with utility maximization,

\footnotetext{
${ }^{6}$ See e.g. Erceg et al. (2001), as well as the textbook treatments in Woodford (2003) and Galí (2007).
} 
subject to demand for their labor services (current and future). ${ }^{7}$ The remaining fraction $\theta_{w}$ keep their nominal wage unchanged. Parameter $\theta_{w} \in[0,1]$ can be thus seen as an index of nominal wage rigidities.

In addition to their wage setting decision, households choose the optimal level and composition of their consumption bundle subject to a sequence of budget constraints. ${ }^{8}$

\subsection{Firms/Technology}

There is a continuum of firms, each of which produces a differentiated good using the technology

$$
Y_{t}=A_{t} N_{t}^{1-\alpha}
$$

where $Y_{t}$ is output, $N_{t}$ is an employment bundle consisting of a CES function of the different types of workers employed, and $A_{t} \equiv \exp \left\{a_{t}\right\}$.is a stochastic preference parameter (common to all firms) which evolves according to the exogenous $A R(1)$ process:

$$
a_{t}=\rho_{a} a_{t-1}+\varepsilon_{t}^{a}
$$

Each period, a subset of firms of measure $1-\theta_{p}$, drawn randomly, reoptimize the price of their good, subject to a sequence of demand schedules for the latter. The remaining fraction $\theta_{p}$ keep their price unchanged. Parameter $\theta_{p} \in[0,1]$ can thus be interpreted as an index of price rigidities. All firms meet the demand for their respective goods at the posted prices.

\footnotetext{
${ }^{7}$ The above description of households and the environment they face, based on the original model by Erceg et al. (2000), does not give rise to a natural notion of unemployment, since each household itself sets the wage of its members subject to a labor demand schedule, thus effectively choosing the level of employment. In Galí (2011) I propose a reformulation of that environment, with wages set at a level above the household (e.g. by unions), which allows one to introduce a meaningful notion of labor force (or participation) and thus to define unemployment as the difference between labor force and employment consistent with existing measurements. Since the focus of the analysis below (as in the General Theory) is on employment and its fluctuations I will stick to Erceg et al.'s original formulation.

${ }^{8}$ The presence of complete markets guarantees that in equilibrium consumption is the same across households, despite their having potentially different wages and, hence, different employment and labor income levels.
} 


\subsection{Monetary Policy}

The central bank's policy is described by a Taylor-type rule of the form

$$
i_{t}=\rho+\phi_{\pi} \pi_{t}+\phi_{y} y_{t}
$$

where $\rho \equiv-\log \beta$ is the discount rate, $i_{t}$ is the nominal interest rate, $\pi_{t}$ is the rate of inflation between $t-1$ and $t, y_{t}$ denotes the $(\log )$ deviations of output from steady state.

\subsection{Discussion}

The New Keynesian model described above includes a number of simplifying assumptions. Firstly, the model does not allow for investment and capital accumulation. This contrasts with Keynes's General Theory, in which fluctuations in investment, often driven by businessmen's animal spirits, are viewed as the key driving force behind economic fluctuations. But that role is taken up in the model by consumption, which shares two key properties with Keynes's model of investment: it responds to changes in interest rates and it is subject to exogenous fluctuations (resulting from the preference shifter $X)$. Secondly, the model abstracts from the existence of a fiscal sector and, like the General Theory, assumes a closed economy. The former assumption is innocuous for the issues at hand, but the latter isn't. Some of the possible implications of opening the economy are discussed in Section 6 below.

Under the assumptions made, the model above features an interesting (and convenient) property: its efficient allocation, which corresponds to that of the Walrasian equilibrium, is characterized by a constant level of employment, given by (in logs): ${ }^{9}$

$$
n_{t}^{e}=\frac{\log (1-\alpha)}{1+\varphi} \equiv n^{e}
$$

${ }^{9}$ The corresponding levels of (log) output, $y_{t}^{e}$, and (log) real wage, $\omega_{t}^{e}$, are given by

$$
\begin{gathered}
y_{t}^{e}=a_{t}+(1-\alpha) n^{e} \\
\omega_{t}^{e}=a_{t}+\left(1-\frac{\alpha}{1+\varphi}\right) \log (1-\alpha)
\end{gathered}
$$

i.e. they adjust one for one with changes in technology, but they are unresponsive to any other shock. 
Accordingly, any observed fluctuations in equilibrium employment are inefficient, and might warrant some stabilization measures. But, as is well known, when both prices and wages are sticky, a tradeoff emerges between stabilization of employment and stabilization of price and wages, for fluctuations in the latter also generate welfare losses, as further discussed below. ${ }^{10}$

\subsection{Calibration}

The various simulations shown below rely on a baseline calibration of the model's structural parameters. Table 1 summarizes that calibration, which is largely consistent with that in Galí (2011). Note, in particular, that the settings for the Calvo stickiness parameters imply an average duration of individual prices and wages of one year, in a way consistent with much of the micro evidence. In addition, the coefficients of the interest rate rule are set at the values proposed by Taylor (1993). The resulting rule is generally viewed as a realistic description of monetary policy in the U.S. (at least in the Volcker-Greenspan period).

\section{Beyond the General Theory: New Insights}

In the present section I briefly revisit two issues pertaining to wages and employment determination on which the New Keynesian model generates insights that depart from the General Theory, or are just not discussed in the latter. The first pertains to the cyclical behavior of wages. The second to the effects of technology shocks on employment.

\subsection{The Cyclical Behavior of Wages}

As discussed above, real wages play an important in Keynes's description of the workings of the economy. In contrast with classical economists, Keynes views wages as being determined by employment (and, indirectly, by aggregate demand), not the other way around. Thus, as shown in Figure 10, fluctuations in aggregate demand generate countercyclical movements in real wages. Formally, this follows from the wage schedule (1), combined with the assumptions of a decreasing marginal product of labor and a constant markup.

\footnotetext{
${ }^{10}$ See, e.g., Erceg et al. (2001), Woodford (2003) and Galí (2008) for a discussion.
} 
The prediction above contrasts with the equilibrium response of the real wage to a positive aggregate demand (preference) shock in the calibrated New Keynesian model, as displayed in Figure 11, and which points to a clear procyclical behavior of the real wage (the Figure also shows the responses of output, employment and inflation, which have the anticipated sign).

The source of real wage procyclicality is well known to researchers familiar with the New Keynesian framework: price stickiness. Thus, when prices are sticky, as assumed in the model used here, the price markup is no longer constant and the wage schedule must be rewritten as

$$
w_{t}-p_{t}=m p n_{t}-\mu_{t}^{p}
$$

When aggregate demand and employment expand, the price markup will generally go down, since the rising marginal cost will not be matched by a commensurate increase in the price level (due to the presence of sticky prices). If the decline in the price markup more than offsets the lower marginal product of labor, the real wage will go up, as in the case depicted in Figure 12.

In the New Keynesian model, the relative degree of wage and price stickiness plays a central role in determining the sign of the real wage response to an aggregate demand shock. This is illustrated in Figure 13, which displays the impact change in the real wage in response to a positive preference shock, as a function of the two parameters governing the degree of price and wage stickiness, respectively (and with the remaining parameters at their baseline values). Note that when both wages and prices are fully flexible the real wage does not change in response to a preference shock, as in the Walrasian equilibrium. The same is true (for obvious reasons) when both wages and prices are completely sticky. More generally, however, the Figure makes clear that the sign of the response of the real wage to a demand shock depends on the relative stickiness of prices and wages, for that determines the size of the change in the average price markup. Thus, and for any given degree of price stickiness, marginal costs will rise less the stickier are wages, and so the decline in the average price markup will be smaller. As a result, the latter will be less likely to offset the downward movement in the marginal product of labor, and the real wage will go down. Conversely, the stickier are prices (conditional on the degree of wage stickiness), the larger is the decline in the markup and, hence, the more likely it is that the real wage rises in response to the positive demand shock. 
The previous finding makes it possible to reconcile the New Keynesian model with existing evidence pointing to a wage rise in response to an expansionary aggregate demand shock. ${ }^{11}$ It also has an important implication for our interpretation of the nature of economic fluctuations: the observation of procyclical real wages (as found, e.g. in the postwar U.S. economy) should not be automatically viewed as evidence against the hypothesis that the business cycle is largely driven by aggregate demand fluctuations.

\subsection{The Effects of Technology Shocks on Employment}

In the General Theory -as in much of macroeconomics before the advent of real business cycle theory- variations in technology are not viewed as a relevant source of economic fluctuations. The latter are instead interpreted as the result of aggregate demand variations, largely due to waves of pessimism and optimism among investors.

Interestingly, however, technology shocks and their effects on the economy provide an excellent testing ground for the predictions of Keynesian vs. classical models. Thus, in classical models an exogenous improvement in aggregate technology raises the marginal product of labor (given employment) thus shifting the labor demand schedule to the right, as shown in Figure 14. In the absence of very strong income effects on labor supply, both employment and the real wage are predicted to rise. Output rises due to the increase in both employment and technology. Hence those models would predict a positive comovement between output and employment in response to technology shocks. ${ }^{12}$

By contrast, the predictions of the Keynesian model regarding the effects of technology shocks on employment are conditioned by the response of aggregate demand to those shocks. Thus, in the limiting case that aggregate demand, and hence output, remain unchanged in response to a positive technology shock, employment would unambiguously decline, for the same amount of output can now be produced with fewer workers. A similar out-

\footnotetext{
${ }^{11}$ See, e.g. Rotemberg and Woodford (1992), Christiano, Eichenbaum and Evans (2005), and Galí, López-Salido and Vallés (2007).

${ }^{12}$ Note that the prediction of such a positive comovement between output and employment in response to technology shocks is a necessary property of any business cycle theory that places a strong weight on those shocks as a source of economic fluctuations, otherwise that theory would be at odds with the observed high positive correlation between employment and output at business cycle frequencies.
} 
come will obtain as long as aggregate demand increases less than proportionally to the increase in technology. This is the case illustrated in Figure 15, which also makes clear that the real wage will rise unambiguously in that case.

Some of the forces at work can be described formally using two equilibrium conditions of the New Keynesian model above. The first condition is the labor demand equation, which follows directly from the production function:

$$
n_{t}=\frac{1}{1-\alpha}\left(y_{t}-a_{t}\right)
$$

The second equilibrium condition is the so-called dynamic IS equation, which combines the household Euler equation with a goods market clearing condition to yield:

$$
y_{t}=E_{t}\left\{y_{t+1}\right\}-\left(i_{t}-E_{t}\left\{\pi_{t+1}\right\}\right)+\left(1-\rho_{x}\right) x_{t}
$$

Iterating (3) forward and substituting into (2) we obtain the following expression for employment:

$$
n_{t}=\frac{1}{1-\alpha}\left(x_{t}-E_{t}\left\{\sum_{k=0}^{\infty}\left(i_{t+k}-E_{t}\left\{\pi_{t+1+k}\right\}\right)\right\}-a_{t}\right)
$$

Equation (4) makes clear that the impact of technology or preference shocks on employment will depend on the induced changes in current and anticipated real interest rates, thus pointing to the key role played by the endogenous component of monetary policy in determining aggregate demand and, consequently, employment.

What is the calibrated New Keynesian model's prediction regarding the effects of technology shocks on employment given a realistic description of monetary policy? To the extent that the rule proposed by Taylor (1993) provides a good approximation to actual monetary policy, the answer can be found in Figure 16: a positive technology shock raises output and the real wage, but lowers both employment and inflation. Thus, the rule followed by the monetary authority does not raise aggregate demand sufficiently to prevent a decline in employment.

The above prediction of the New Keynesian model regarding the effect of technology shocks on employment has received a good amount of empirical support, as exemplified by the VAR-based evidence in Galí (1999), Basu, Fernald and Kimball (2006), Francis and Ramey (2005) and Barnichon (2010), 
among others. Furthermore, the implication that the response of employment should not be invariant to changes in the policy rule also seems to be consistent with the evidence, as shown in Galí, López-Salido and Vallés (2003) and Fisher (2006), among others, who compare the estimated responses across the pre-Volcker and Volcker-Greenspan periods . Finally, it is worth noting estimated DSGE models, which allow for a much richer structure than the simple model described below, also generate an employment decline in response to a positive technology shock (see, e.g., Galí and Rabanal (2004) and Smets and Wouters (2003, 2007)).

\section{The Case for Wage Flexibility Revisited}

Next I use the New Keynesian model to study the role of wage flexibility as a factor of macroeconomic stability, with a focus on employment. I pose the following question: What is the impact of greater wage flexibility on the volatility of employment and on welfare?

Under a classical logic, greater wage flexibility will contribute to employment stability to the extent the reductions in wages during downturns stimulate employment, thus dampening the initial impact of an adverse shock. To what extent this is the case in the New Keynesian model? Before I analyze the impact of enhanced wage flexibility I take a brief detour and examine the New Keynesian model's implications regarding the effectiveness of reductions in wages (or other components of labor costs) at promoting employment.

Again, the answer to that question is not an unconditional one: it depends on the monetary policy rule in place. In other words, it hinges on the change in aggregate demand induced by variations in wages and labor costs. To see this more formally, consider the expression for employment in equation (4) (interpreted as deviations from steady state) and assume that the central bank's response implies a constant real interest rate. ${ }^{13}$ Thus we can rewrite the expression for employment as

$$
n_{t}=\frac{1}{1-\alpha}\left(x_{t}-a_{t}\right)
$$

We see that in that case employment depends exclusively on the exogenous driving forces themselves, and is fully decoupled from wages. In other

\footnotetext{
${ }^{13}$ See Woodford (2011) for a similar approach in the context of an analysis of the impact of changes in government purchases.
} 
words, there is no direct impact of wage adjustments on labor demand and employment. The mechanism through which changes in wages may end up affecting employment operates in the New Keynesian model through the induced response of monetary policy. In particular, a decline in nominal wages is expected to bring down inflation, lower the nominal and real interest rates, and stimulate output and employment. This highlights the importance of the endogenous component of monetary policy in determining the effectiveness of changes in labor costs (and, as we will see later, in changes in the degree of wage flexibility as well).

To illustrate the previous point, I simulate the response of employment to decline in a payroll tax (equivalently, a rise in an employment subsidy) and look at the dependence of that response on the strength of the central bank's response to inflation, measured by $\phi_{\pi}$. I assume that the payroll tax follows an $A R(1)$ process with autoregressive coefficient of 0.9 , with a decline on impact of 1 percent. Figure 17 displays the implied impulse responses for a range of $\phi_{\pi}$ values in the $(1,2]$ interval. When the central bank's response to inflation is weak, aggregate demand and, hence, employment remain hardly changed. On the other hand, when the central bank lowers interest rates aggressively in response to the inflation decline induced by the cut in payroll taxes the effect on employment is substantial. The figure makes clear that the effectiveness of the exogenous policy intervention depends critically on the central bank's response to inflation. The decline in the payroll tax has, by itself, no effect if unaccompanied by an expansion in aggregate demand.

Next I turn to the analysis of the consequences of changes in the degree of wage flexibility. Figure 18 display the standard deviation of (log) employment as a function of the degree of wage stickiness $\left(\theta_{w}\right)$ and the inflation coefficient in the interest rate rule $\left(\phi_{\pi}\right)$, conditional on technology shocks being the source of fluctuations (see below for the corresponding results conditional on preference/demand shocks). The remaining parameters are kept at their baseline values. The Figure points to a decline in the volatility in employment as the degree of wage stickiness is reduced, independently of monetary policy. The size of the decline, however, is strongly dependent on the central bank's response to inflation. When the latter is strong, a small increase in wage flexibility leads to a large improvement in terms of employment stability. By contrast, when the inflation coefficient is close to unity, the gains in stability that result from a given reduction in the stickiness parameter are much smaller, especially in the empirically relevant range of $\theta_{w}$ (say, around $0.75)$. 
What are the effects of greater wage flexibility on welfare? Figure 19 shows the average welfare losses as a function of $\theta_{w}$ and $\phi_{\pi}$, again conditional on technology shocks. I measure average welfare losses of the model's representative household using the second order approximation ${ }^{14}$

$$
\mathbb{L} \sim(1+\varphi) \operatorname{var}\left(n_{t}\right)+\left(\frac{\epsilon_{p}}{\lambda_{p}(1-\alpha)}\right) \operatorname{var}\left(\pi_{t}^{p}\right)+\left(\frac{\epsilon_{w}}{\lambda_{w}}\right) \operatorname{var}\left(\pi_{t}^{w}\right)
$$

where $\lambda_{p} \equiv \frac{\left(1-\theta_{p}\right)\left(1-\beta \theta_{p}\right)}{\theta_{p}} \frac{1-\alpha}{1-\alpha+\alpha \epsilon_{p}}$ and $\lambda_{w} \equiv \frac{\left(1-\theta_{w}\right)\left(1-\beta \theta_{w}\right)}{\theta_{w}\left(1+\epsilon_{w} \varphi\right)} \cdot{ }^{15}$

Note that the sign of the effect is no longer unambiguous, showing instead a strong dependence on the rule's inflation coefficient. When the latter is large (close to 2), enhanced wage flexibility reduces average welfare losses. But the relation becomes non-monotonic for intermediate values of $\phi_{\pi}$. In that case, welfare losses increase if wages are made more flexible when starting from an initial condition with sufficiently sticky wages. Finally, and perhaps more surprisingly, when the inflation coefficient is close to unity, average welfare losses always increase, and substantially so, in response to greater wage flexibility.

Figure 20 allows one to uncover the respective role played by the three additive terms in (5) in determining total welfare losses. Not surprisingly (given Figure 18), greater wage flexibility reduces the contribution of employment volatility to welfare losses. By contrast, it raises the contribution of price inflation volatility, since prices reflect the greater volatility in nominal wages induced by the rise in wage flexibility. Finally, the contribution of wage inflation volatility is non-monotonic, independently of the strength of the monetary policy response. This is the result of the interaction of two factors. On the one hand, the volatility of wage inflation is increasing when wages become more flexible, as noted above. But that effect must be balanced against the smaller losses resulting from any given volatility of wage inflation, as reflected in a smaller weight $\epsilon_{w} / \lambda_{w}$. The non-monotonicity follows from continuity and the fact that in the limiting cases of constant $\left(\theta_{w} \rightarrow 1\right)$ and fully flexible $\left(\theta_{w} \rightarrow 0\right)$ nominal wages, the contribution of the wage inflation component is zero.

In Figures 21-23 I report information analogous to that in the Figures 18-20 but conditional on demand/preference shocks as the only source of

\footnotetext{
${ }^{14}$ See, e.g. Galí (2008, p141-143), after the trivial substitution using $\widetilde{y}_{t}=(1-\alpha) \widetilde{n}_{t}$.

${ }^{15} \mathrm{As}$ is common in the literature I assume the presence of a constant employment subsidy that exactly offsets the distortions generate by market power, rendering the steady state efficient.
} 
fluctuations. Note that all the qualitative results observed under the assumption of technology shocks carry over to this case.

Finally, I turn to the case of optimal monetary policy. The latter is described by a set of seven stochastic difference equations, which include the optimality conditions associated with the problem of welfare loss minimization (under commitment) subject to the equations constituting the non-policy block of the model's equilibrium (see, e.g. Galí (2008, ch. 6) for a derivation and discussion). When preference shocks are the source of fluctuations the optimal policy takes a simple form: it involves the full stabilization of employment, as well as price and wage inflation. In other words, the natural allocation can be replicated and no trade-offs emerge. By contrast when technology shocks are the driving force, the optimal policy must strike a balance between stabilization of the three welfare relevant variables.

Figure 24 shows the welfare loss under the optimal policy as a function of the degree of wage stickiness, for the baseline calibration. The graph uncovers a monotonic relationship: greater wage flexibility appears to be welfare-enhancing in this case. Figure 25 shows the three components of welfare losses. Note that the component associated with wage inflation is non-monotonic, capturing the interaction between the greater volatility of wage inflation and the smaller cost of any given wage inflation volatility associated with greater wage flexibility. That pattern is, however, completely dominated by the decline in the contribution of price inflation volatility as wages become more flexible. The latter, follows from the fact that as the importance of wage stickiness diminishes the central bank puts an increasing (relative) weight on price stabilization.

Is the monotonic relation shown in Figure 24 a general result when the central bank follows an optimal policy, i.e. does it depend on the specific calibration used? If it were general, we could attribute the negative effect of greater wage flexibility on welfare uncovered earlier (see Figures 19 and 22) exclusively to the central bank following a particular sub-optimal policy (a Taylor-like rule, to be specific).

The monotonic relation between wage flexibility and welfare turns out not be a general result. Figure 26 displays the welfare loss under the optimal policy for an alternative calibration of the model characterized by extreme price stickiness $\left(\theta_{p}=0.97\right)$. The monotonicity is now lost: when the initial degree of wage stickiness is sufficiently high, a marginal increase in wage flexibility is shown to be detrimental to welfare. Figure 27 displays the decomposition of the previous welfare loss, pointing to the joint role of the 
wage inflation and the employment components as the explanation behind the larger welfare losses resulting from greater wage flexibility. Intuitively, and due to the large distortions associated with price instability under the present calibration, the central bank focuses nearly exclusively on stabilizing price inflation. More wage flexibility leads to greater volatility of wage inflation, making stabilization of price inflation more costly in terms of employment volatility.

\section{Some Caveats}

Next I briefly discuss several caveats associated with the analysis above. All of them can be potentially overcome by a suitable extension (along familiar grounds) of the framework used above.

A first caveat of my analysis has to do with the use of a closed economy framework, a feature in common with much of the discussion contained in the General Theory. Keynes himself pointed to the limitations implied by the assumption of a closed economy, since the latter disregards the "competitiveness channel" often emphasized in policy debate on the desirability of wage flexibility. In an open economy, it is argued, lower nominal wages would lead to lower prices for domestic goods and -in the absence of any offsetting variations in the nominal exchange rate- a depreciation of the real exchange rate, which would stimulate net exports, aggregate demand and employment. The effectiveness of the previous channel seems to depend, however, on two factors. First, the degree to which lower marginal costs are reflected in lower prices for exported goods. Existing evidence on the importance of pricing to market in international trade suggests that the relevant relative prices may end up reflecting only part of the wage adjustment, thus limiting any expansionary impact on employment. Secondly, the nature of the endogenous monetary policy response will determine how the nominal exchange rate adjusts. Thus, if the central bank follows a Taylor-like rule, the expansionary impact of a downward nominal wage adjustment will be stronger the larger (smaller) is the weight attached to inflation (output) stabilization.

A second caveat pertains to the assumption of identical households. Relaxing that assumption along some dimensions may have implications for the impact of wage adjustments on employment. In particular, if a fraction of households behave in a non-Ricardian fashion, i.e. equating their consumption to their current labor income, a reduction in wages may lead, through 
this channel, to a reduction in aggregate consumption and, as a result, in aggregate demand and employment.

A final caveat has to do with the monetary policy response. In the analysis above, I have assumed that the central bank follows a Taylor-like rule. Yet, there are many real world instances in which that rule will not constitute a reasonable approximation to the monetary policy response. In particular, in the case of a currency union, the (common) interest rate is unlikely to adjust at all in response to the fall in inflation experienced by an member country due to lower wages. The same is true in a country in which, despite having its own monetary policy, interest rates have hit a zero lower bound. In such circumstances, when the nominal rate cannot adjust downward, a wage cut may have contractionary effects on aggregate demand and employment if it triggers expectations of lower inflation down the road and, hence, leads to higher real interest rates.

The standard New Keynesian model used as a reference framework in the present paper does not account for any of the three previous factors (open economy, non-Ricardian behavior and constraints on monetary policy). Given their relevance, the explicit incorporation of those factors in the analysis seems to be warranted in order to get a better assessment of the role of wage flexibility in the determination of employment and welfare. This is an avenue that I plan to pursue in future work.

\section{Concluding Remarks}

The main objective of the work presented here was to revisit some of the key themes and propositions in Keynes's General Theory through the lens of the New Keynesian model, the workhorse of modern macroeconomic theory. I have focused on the role of wages vs. aggregate demand in the determination of employment, an issue at the core of Keynes's critique of classical economics.

The exercise yields a number of tentative conclusions. Firstly, many of Keynes's key insights on the above subject seem to stand up to the scrutiny of New Keynesian theory. Thus, in the latter, as in the General Theory, wage adjustments do not play a direct role in the determination of employment. Their eventual impact on employment is only indirect, through the change in aggregate demand resulting from the endogenous monetary policy response to the variations in inflation caused by the wage adjustments. Accordingly, the monetary policy rule in place will be critical in determining the degree 
to which more wage flexibility can play a stabilizing role.

Despite the overall consistency of the New Keynesian framework with the main qualitative propositions in the General Theory, the former provides some insights absent from Keynes's book, namely, (i) the possibility of procyclical real wages when prices are sufficiently sticky relative to wages, and (ii) the likely contractionary effects of positive aggregate technology shocks on employment.

The New Keynesian model makes it possible to evaluate the desirability of enhanced wage flexibility from a welfare perspective. Above, I have shown that it is not generally true that welfare is higher when wages are more flexible. In particular, when the central bank follows a Taylor-type rule which responds weakly to price inflation, the opposite may be true for reasonable parameter values. By contrast, when an optimal monetary policy is in place, more flexible wages tend to raise welfare for plausible calibrations of the model. That result can be overturned, though, if prices display extreme stickiness.

All things considered, the findings of the present paper suggest that the effectiveness of downward labor cost adjustment in fighting unemployment and, more generally, the desirability of more wage flexibility are questions whose answers are more nuanced that what we may have thought. Of course, none of this would have come as a surprise to John Maynard Keynes. 


\section{References}

Barnichon, Régis (2010): "Productivity and Unemployment over the Business Cycle," Journal of Monetary Economics, 57 (8), 2010, 1013-1025.

Basu, Susanto, John Fernald, and Miles Kimball (2006): "Are Technology Improvements Contractionary?," American Economic Review, vol. 96, no. $5,1418-1448$.

Christiano, Lawrence J., Martin Eichenbaum, and Charles L. Evans (2005): "Nominal Rigidities and the Dynamic Effects of a Shock to Monetary Policy," Journal of Political Economy, vol. 113, no. 1, 1-45

European Central Bank (2012), Monthly Bulletin, August.

Hansen, Alvin H. (1953): A Guide to Keynes, McGraw-Hill Book Company, New York.

Hicks, John R. (1937): "Mr. Keynes and the "Classics"; A Suggested Interpretation," Econometrica, vol. 5 (2), 147-159.

Keynes, John Maynard (1936): The General Theory of Employment, Interest and Money, Macmillan, London.

Patinkin, Don (1948): "Price Flexibility and Full Employment," American Economic Review 38, 543-564.

Erceg, Christopher J., Dale W. Henderson, and Andrew T. Levin (2000): "Optimal Monetary Policy with Staggered Wage and Price Contracts," Journal of Monetary Economics vol. 46, no. 2, 281-314.

Fisher, Jonas D.M. (2006): "The Dynamic Effects of Neutral and InvestmentSpecific Technology Shocks," Journal of Political Economy, 114 (3), 413-451.

Francis, Neville, and Valerie Ramey (2005): "Is the Technology-Driven Real Business Cycle Hypothesis Dead? Shocks and Aggregate Fluctuations Revisited," Journal of Monetary Economics, vol. 52, issue 8,1379-1399

Galí, Jordi (1999): "Technology, Employment, and the Business Cycle: Do Technology Shocks Explain Aggregate Fluctuations?," American Economic Review, vol. 89, no. 1, 249-271.

Galí, Jordi (2008): Monetary Policy, Inflation and the Business Cycle: An Introduction to the New Keynesian Framework, Princeton University Press (Princeton, NJ).

Galí, Jordi (2011): Unemployment Fluctuations and Stabilization Policies: A New Keynesian Perspective, MIT Press (Cambridge, MA).

Galí, Jordi, J. David López-Salido and Javier Vallés (2007): "Understanding the Effects of Government Spending on Consumption," Journal of the European Economics Association, vol. 5, issue 1, 227-270. 
Galí, Jordi, J. David López-Salido, and Javier Vallés (2003): "Technology Shocks and Monetary Policy: Assessing the Fed's Performance," Journal of Monetary Economics, vol. 50, no. 4., 723-743.

Galí, Jordi and Pau Rabanal (2004): "Technology Shocks and Aggregate Fluctuations: How Well Does the RBC Model Fit Postwar U.S. Data?," NBER Macroeconomics Annual 2004, 225-288.

Rotemberg, Julio J., and Michael Woodford (1992): "Oligopolistic Pricing and the Effects of Aggregate Demand on Economic Activity," Journal of Political Economy, vol. 100, 1153-1207.

Smets, Frank, and Raf Wouters (2003): "An Estimated Dynamic Stochastic General Equilibrium Model of the Euro Area," Journal of the European Economic Association, vol 1, no. 5, 1123-1175.

Smets, Frank, and Raf Wouters (2007): "Shocks and Frictions in US Business Cycles: a Bayesian DSGE Approach," American Economic Review, vol. 97 (3), 586-606.

Taylor, John B. (1993): "Discretion versus Policy Rules in Practice," Carnegie-Rochester Series on Public Policy 39, 195-214.

Woodford, Michael (2003): Interest and Prices: Foundations of a Theory of Monetary Policy, Princeton University Press (Princeton, NJ).

Woodford, Michael (2011): "Simple Analytics of the Government Spending Multiplier," American Economic Journal; Macroeconomics, 3, 1-35. 
Table 1. Baseline Calibration

\begin{tabular}{llcc}
\hline \hline & \multicolumn{1}{c}{ Description } & Value & Target \\
\hline$\varphi$ & Curvature of labor disutility & 5 & Frisch elasticity 0.2 \\
$\alpha$ & Index of decrasing returns to labor & $1 / 4$ & \\
$\epsilon_{w}$ & Elasticity of substitution (labor) & 4.52 & $u^{n}=0.05$ \\
$\epsilon_{p}$ & Elasticity of substitution (goods) & 9 & $S=\frac{1-\alpha}{\epsilon_{p} /\left(\epsilon_{p}-1\right)}=2 / 3$ \\
$\theta_{p}$ & Calvo index of price rigidities & $3 / 4$ & avg. duration $=4$ \\
$\theta_{w}$ & Calvo index of wage rigidities & $3 / 4$ & avg. duration $=4$ \\
$\phi_{p}$ & Inflation coefficient in policy rule & 1.5 & Taylor (1993) \\
$\phi_{y}$ & Output coefficient in policy rule & 0.125 & Taylor (1993) \\
$\beta$ & Discount factor & 0.99 & \\
$\rho_{i}$ & Persistence exogenous processes & 0.9 & \\
\hline \hline
\end{tabular}


Figure 1. The Classical Theory of Employment: Labor Demand

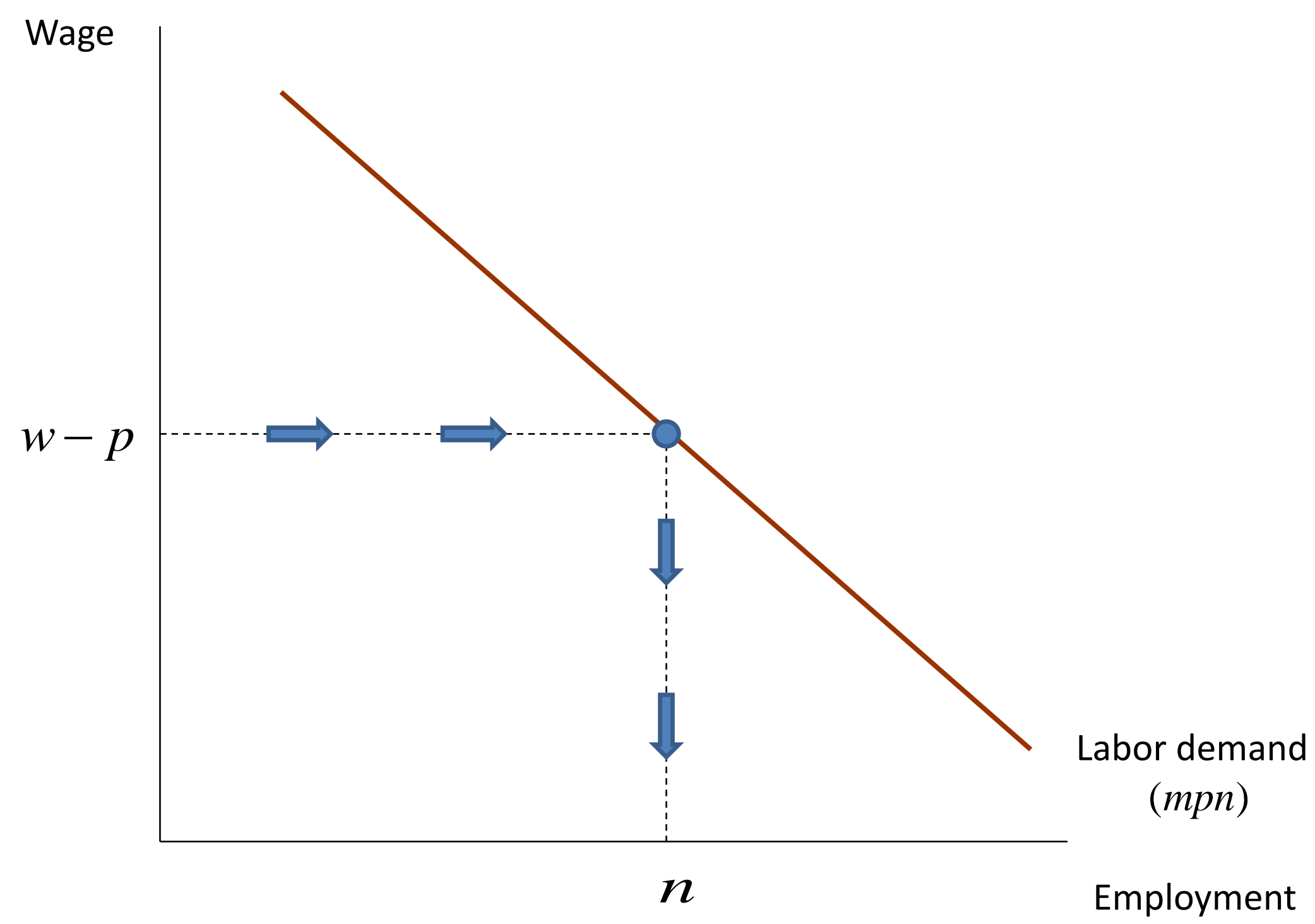


Figure 2. The Classical Theory of Employment: Labor Supply

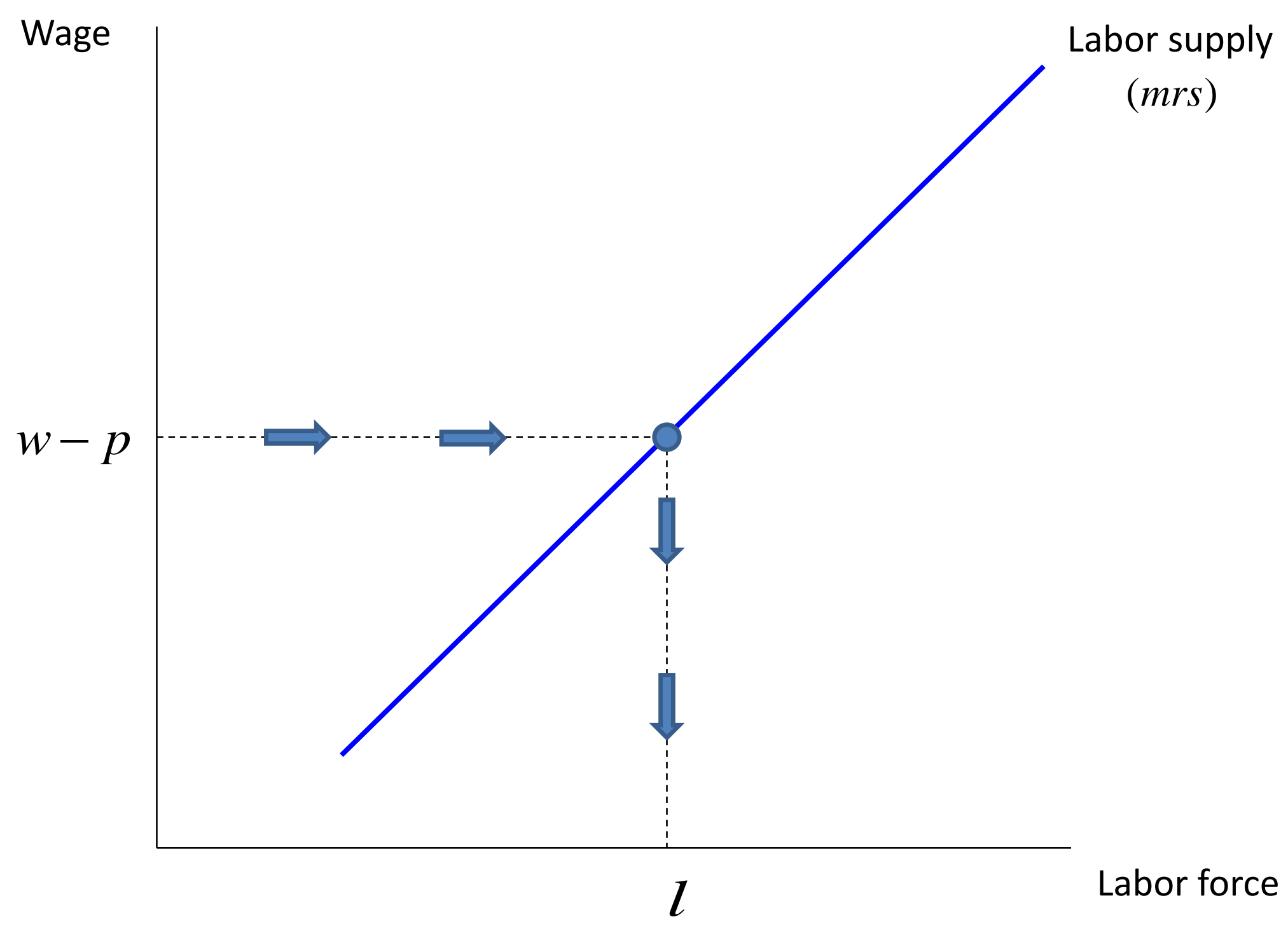


Figure 3. The Classical Theory of Employment: Walrasian Equilibrium

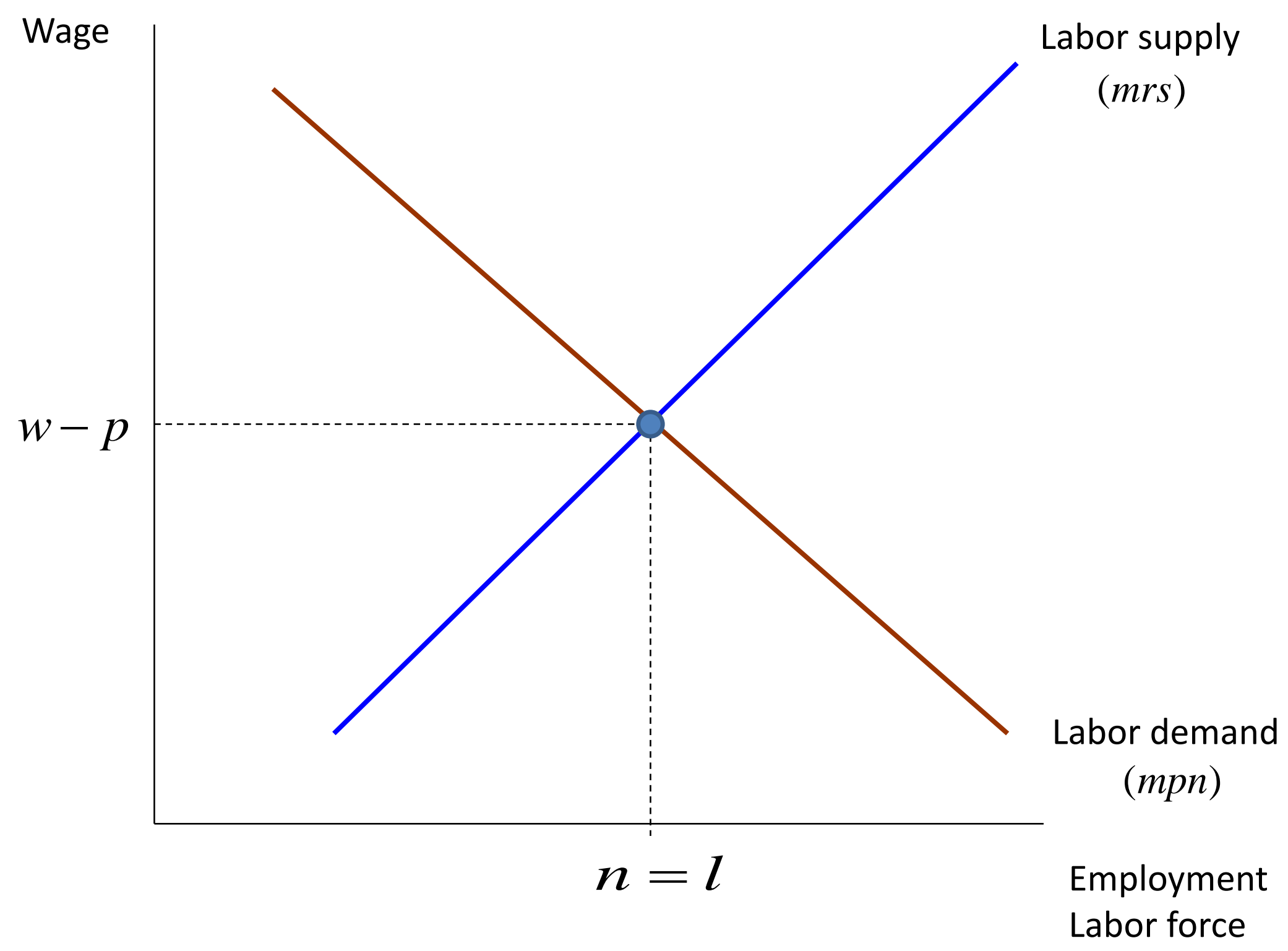


Figure 4. Unemployment in the Classical Theory of Employment

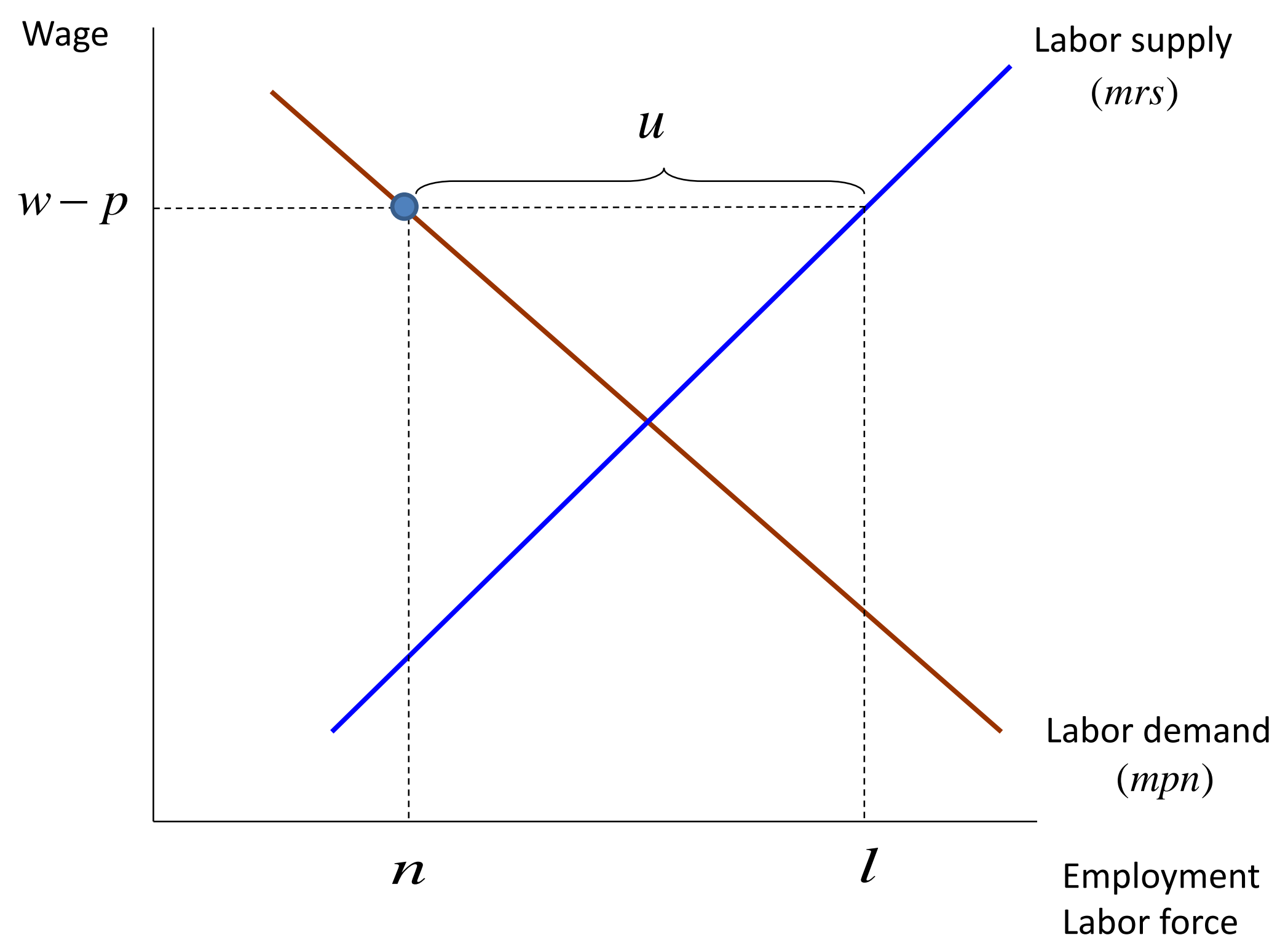


Figure 5. Classical Unemployment Cures (I): Real Wage Reduction

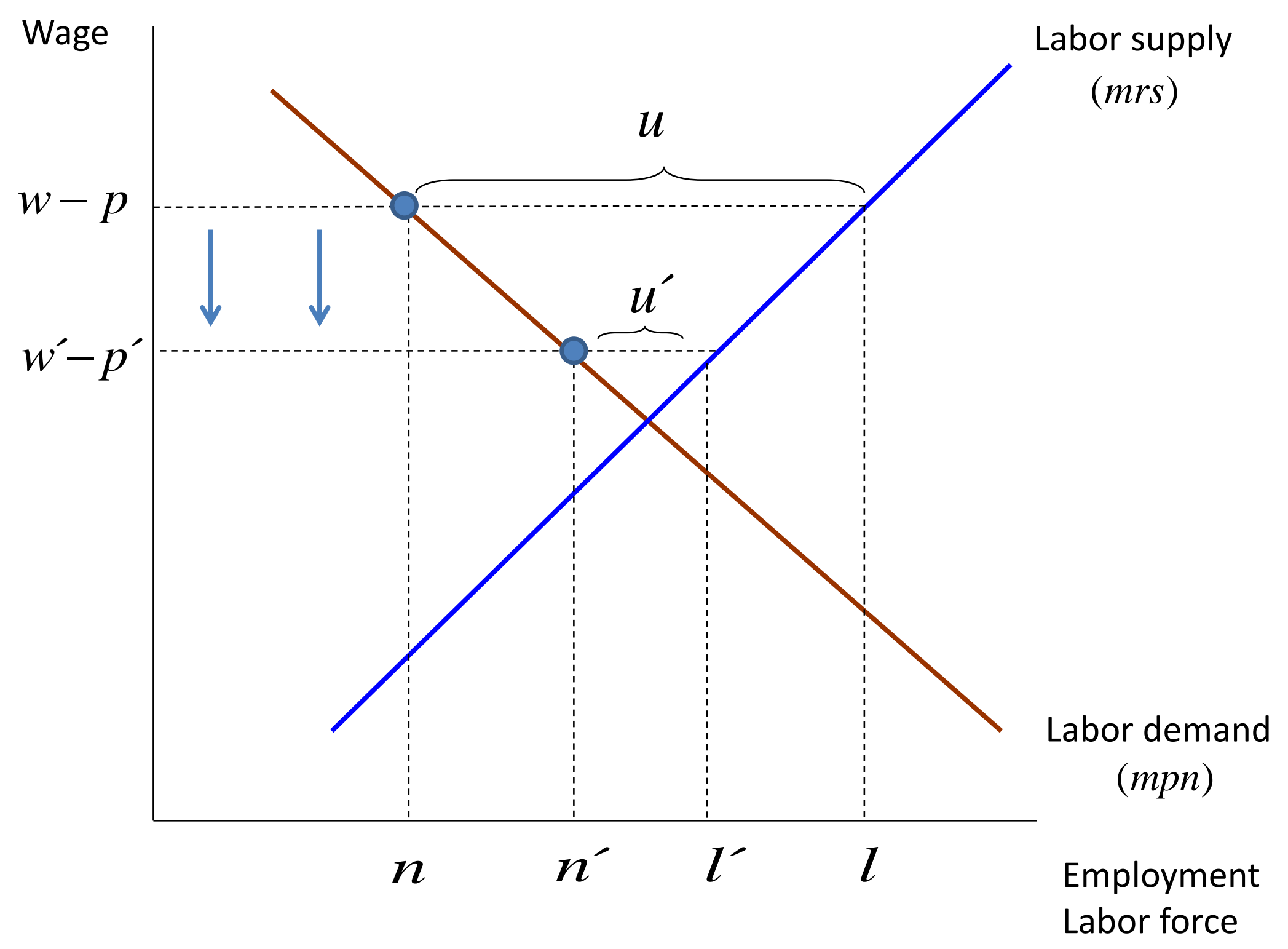


Figure 6. Classical Unemployment Cures (II): Employment Subsidy

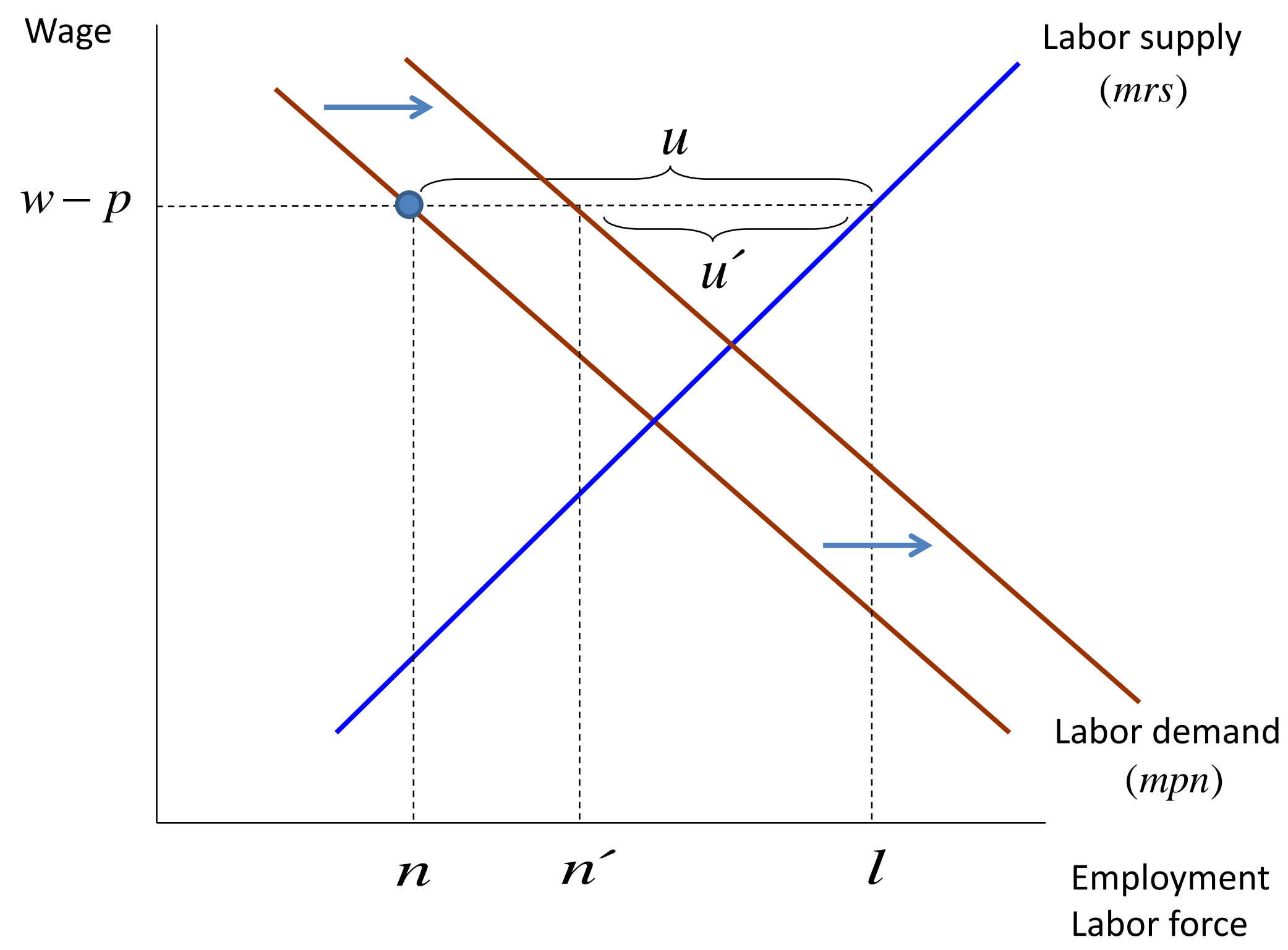


Figure 7. The Keynesian Theory of Employment: Labor Demand

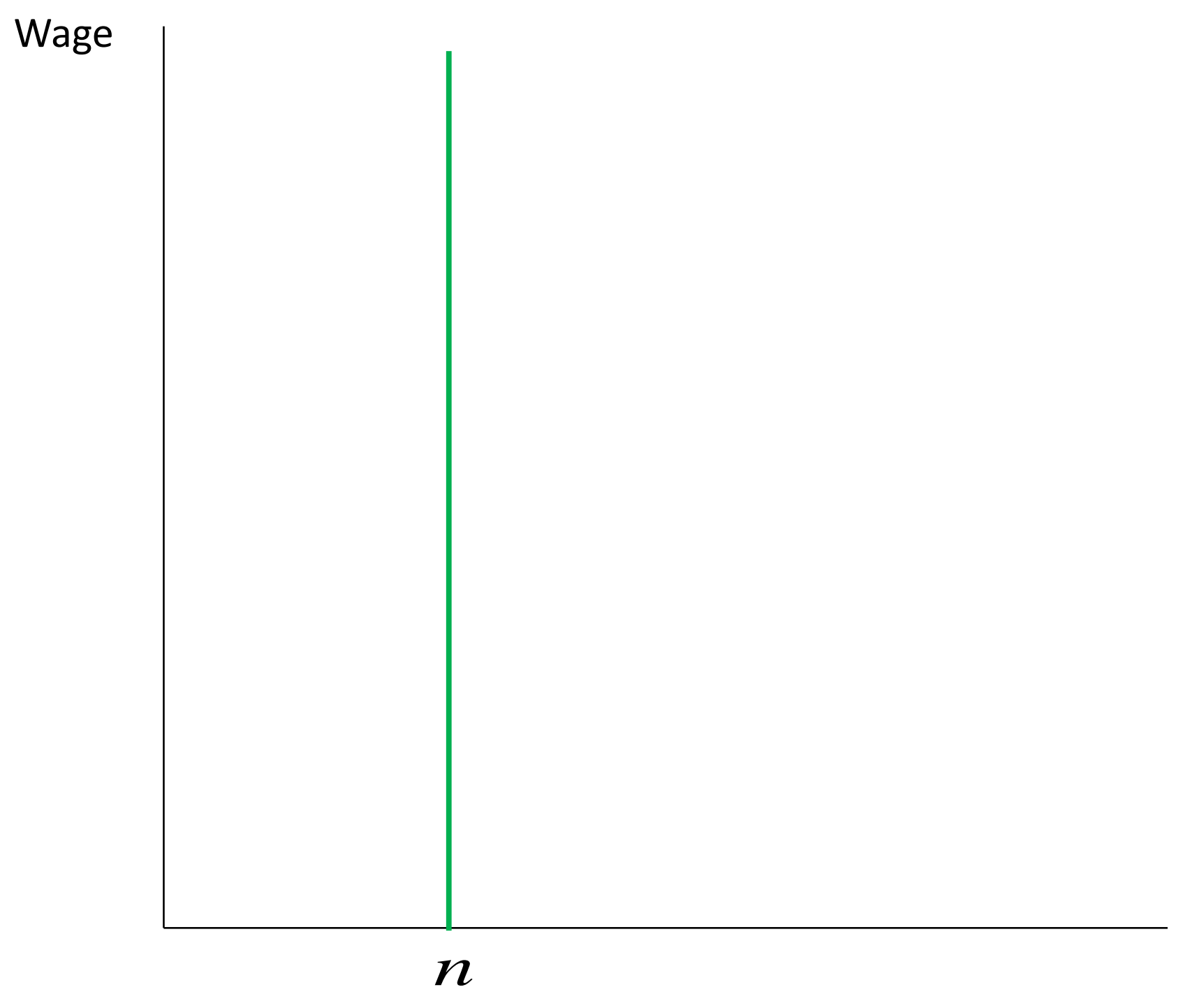


Figure 8. The Keynesian Theory of Employment

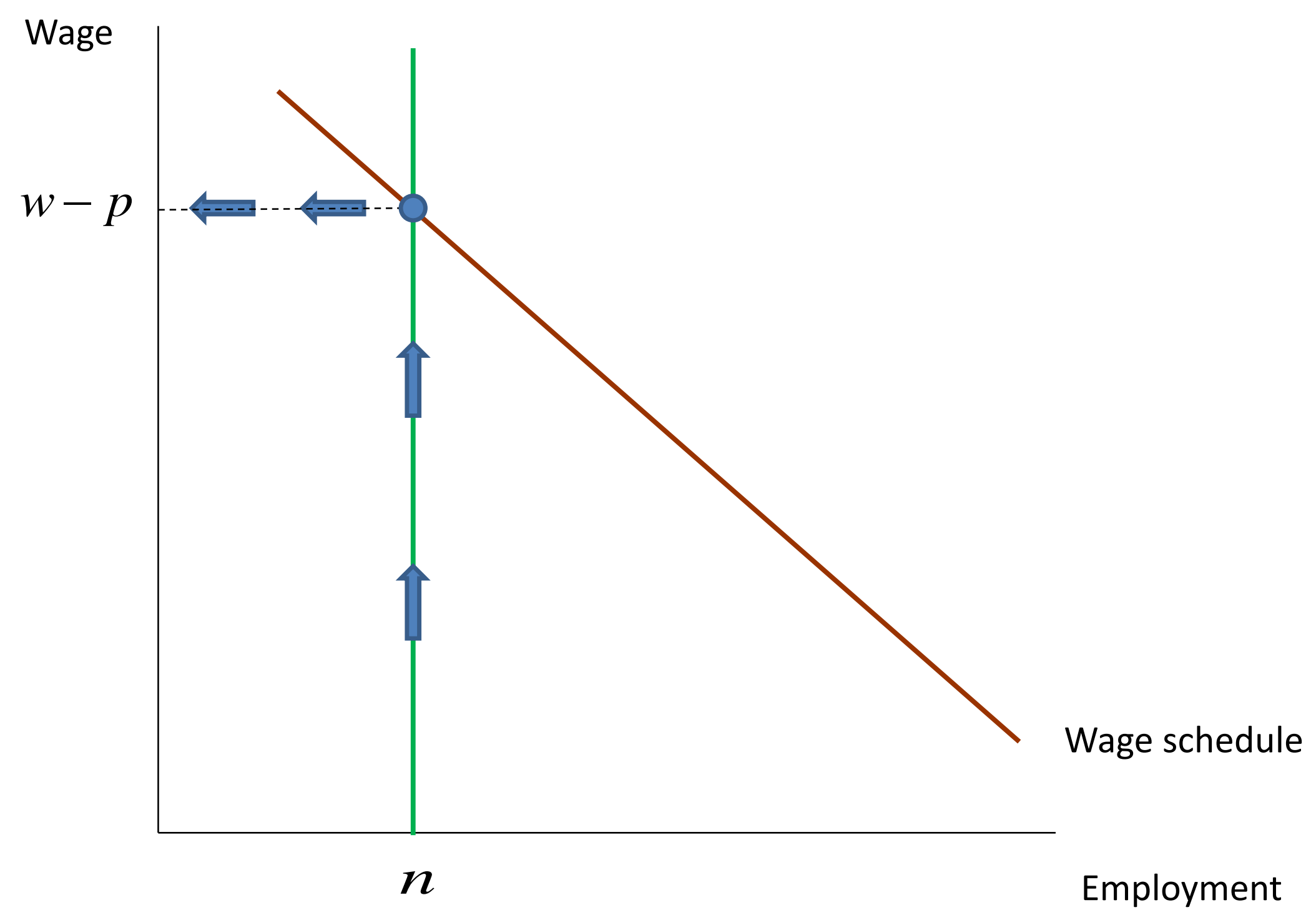


Figure 9. Unemployment in the Keynesian Theory of Employment

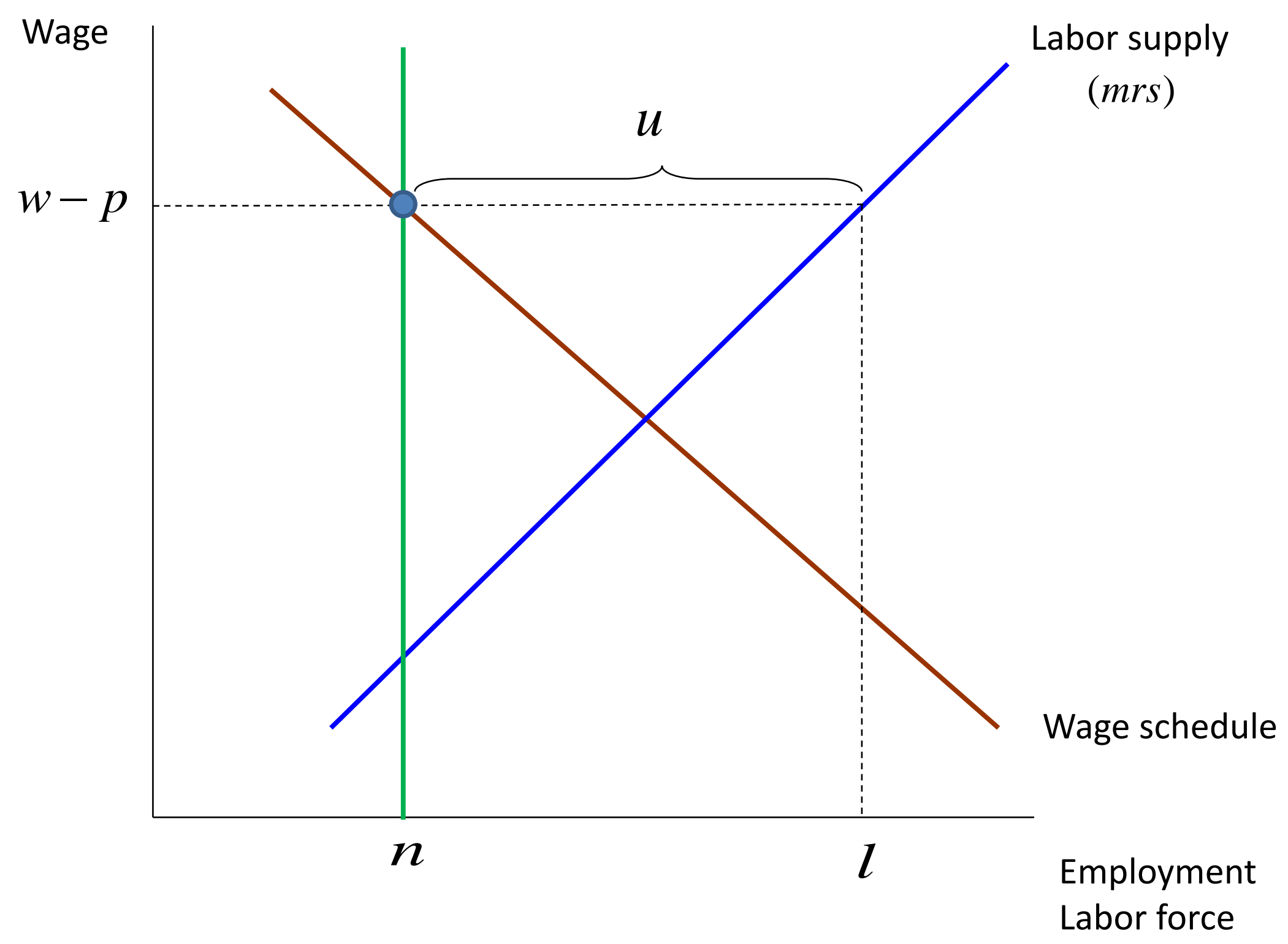


Figure 10. Cure for Keynesian Unemployment: Aggregate Demand Expansion

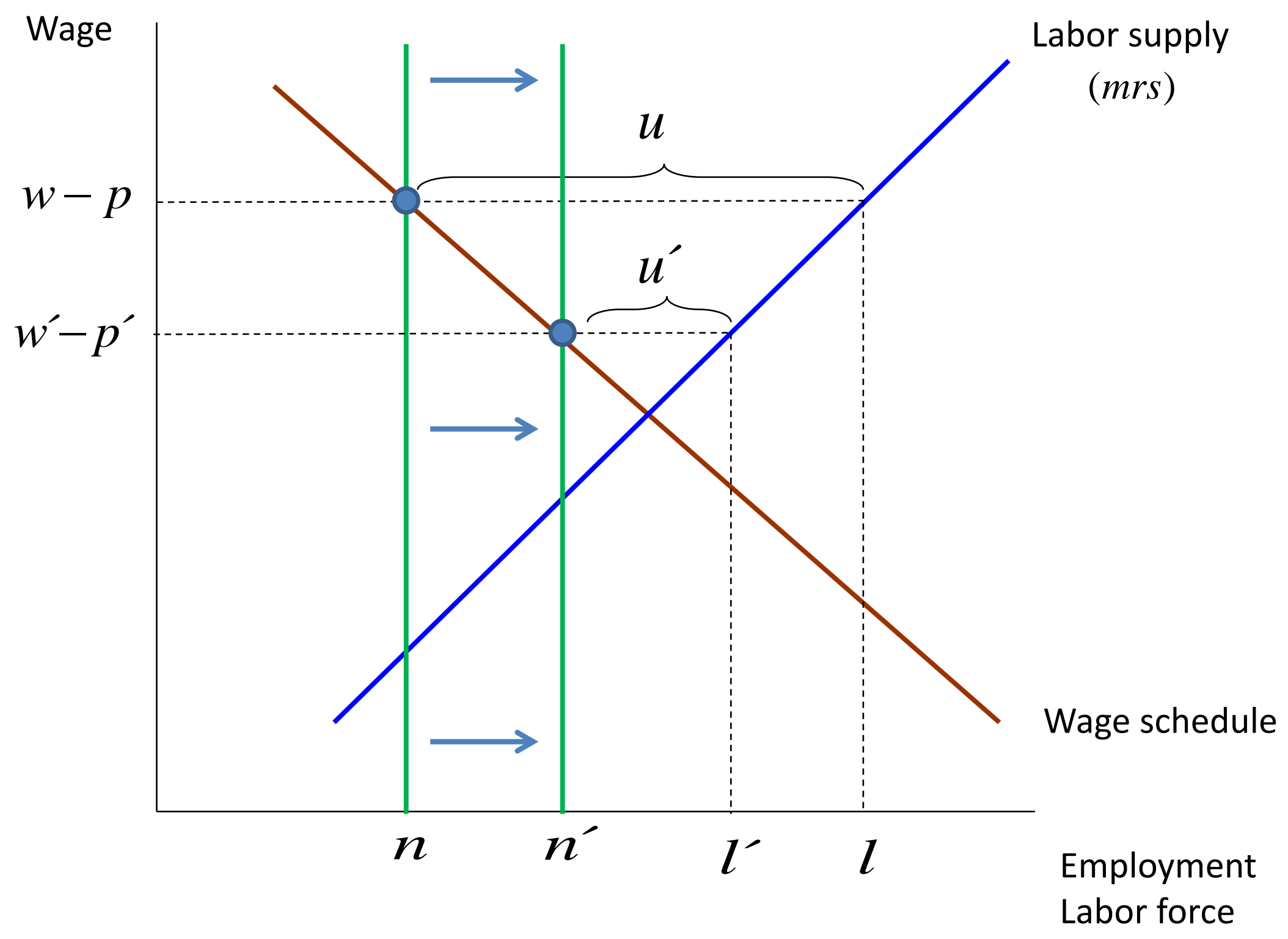


Figure 11. Dynamic Responses to an Aggregate Demand Shock in the NK Model
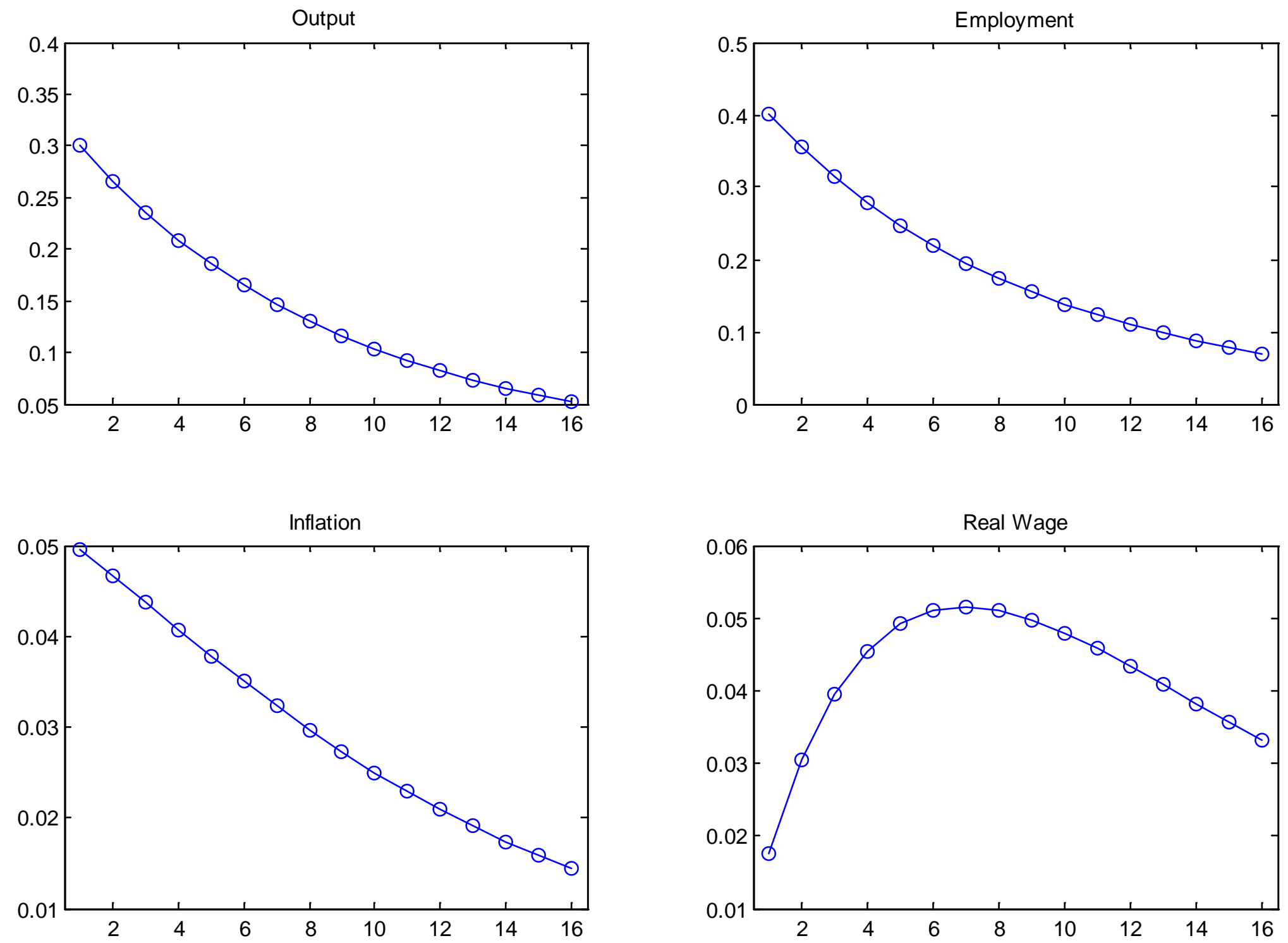
Figure 12. The Effects of an Aggregate Demand Expansion with Sticky Prices

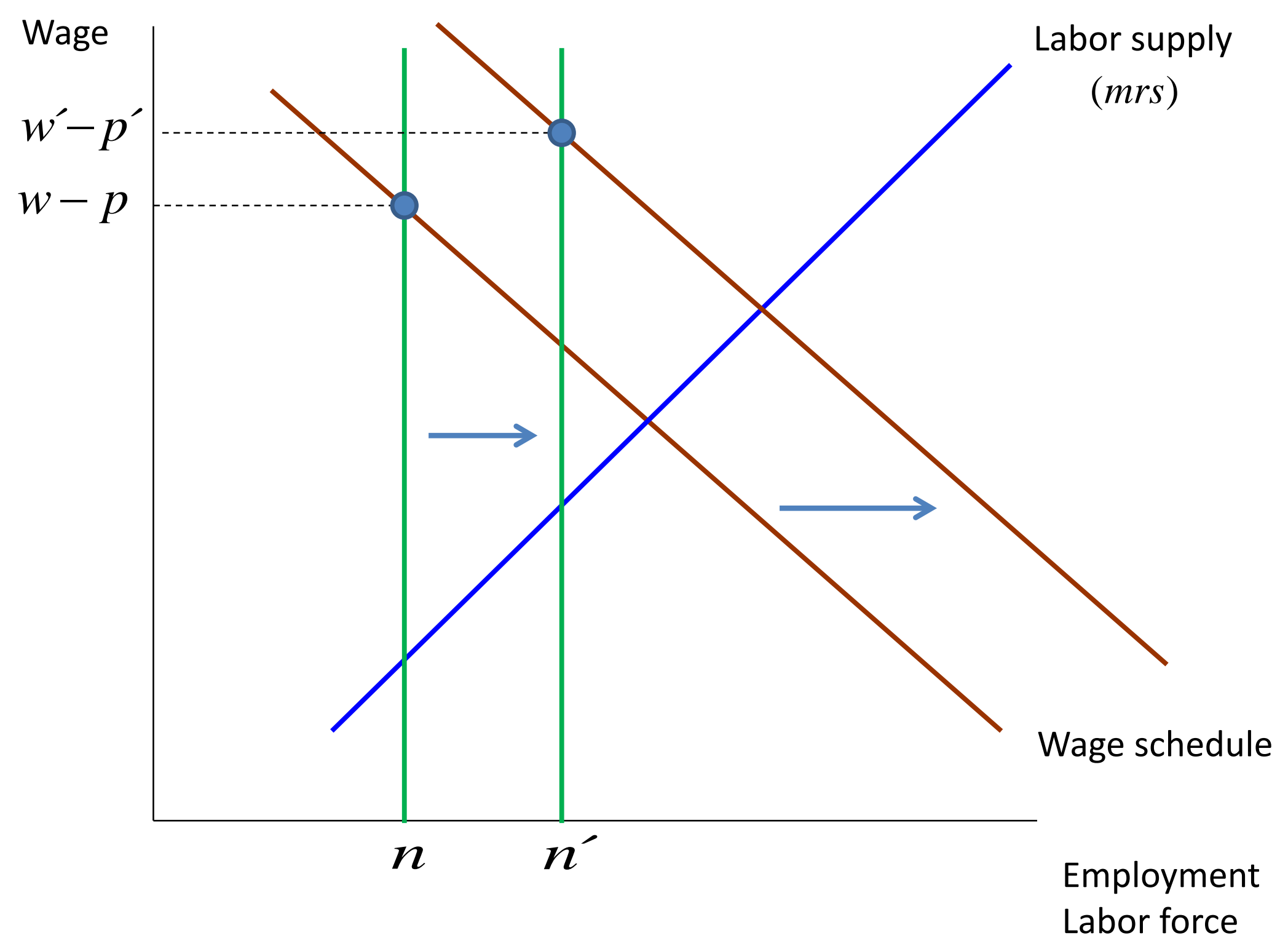




\section{Figure 13}

Impact Response of the Real Wage to an Aggregate Demand Shock in the NK Model

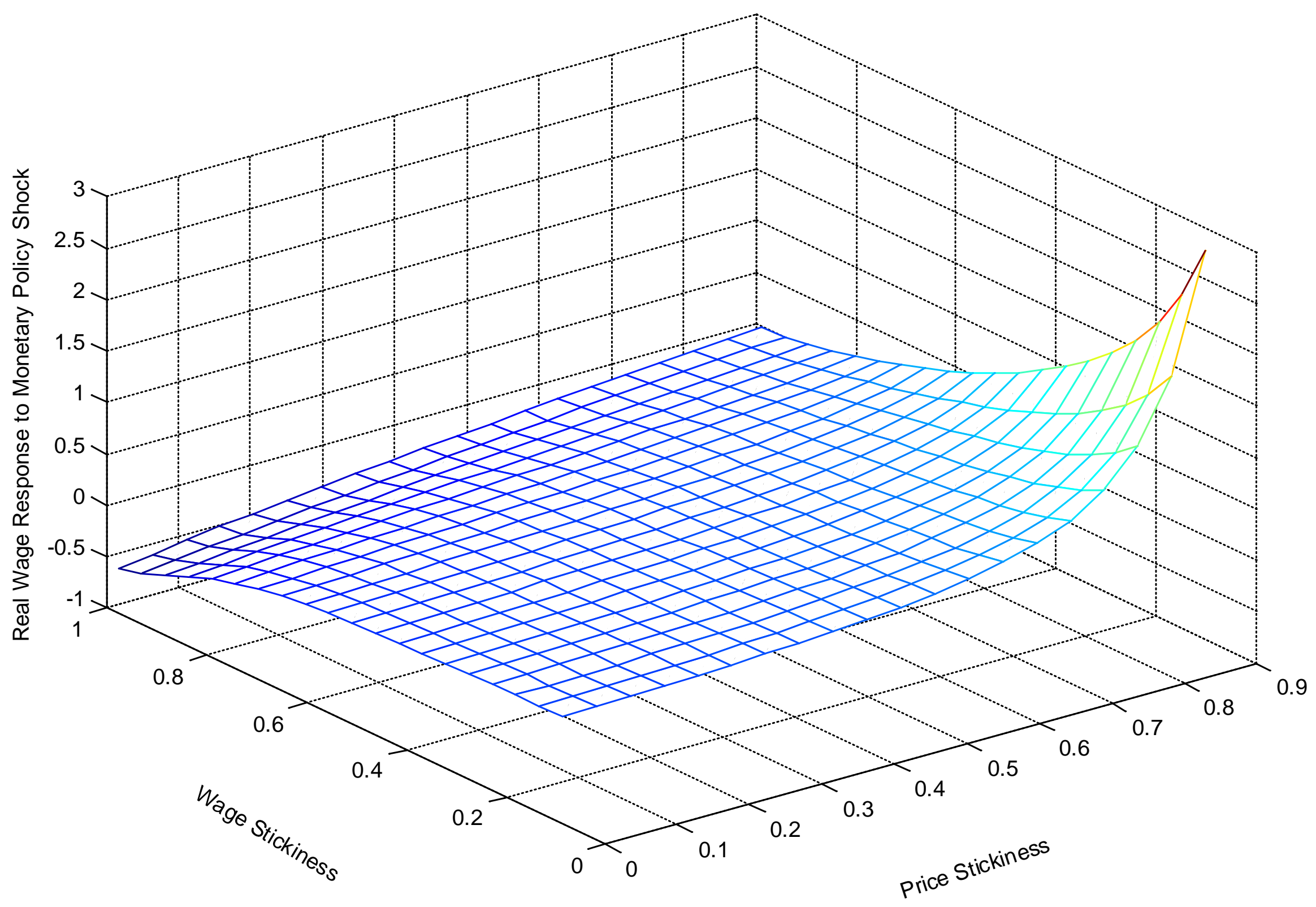


Figure 14. The Effects of Technology Shocks on Employment: the Classical Model

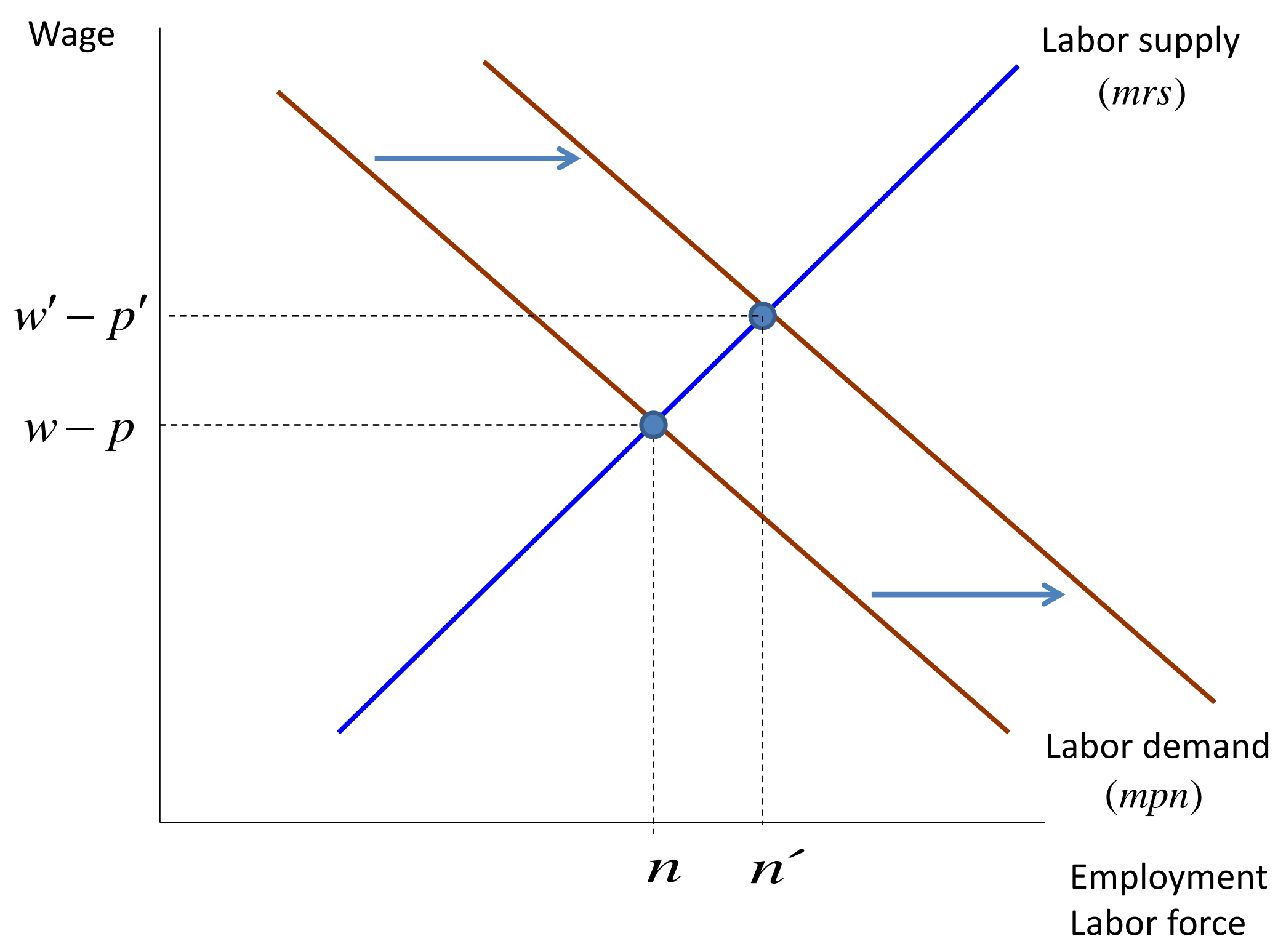


Figure 15. The Effects of Technology Shocks on Employment: the Keynesian Model

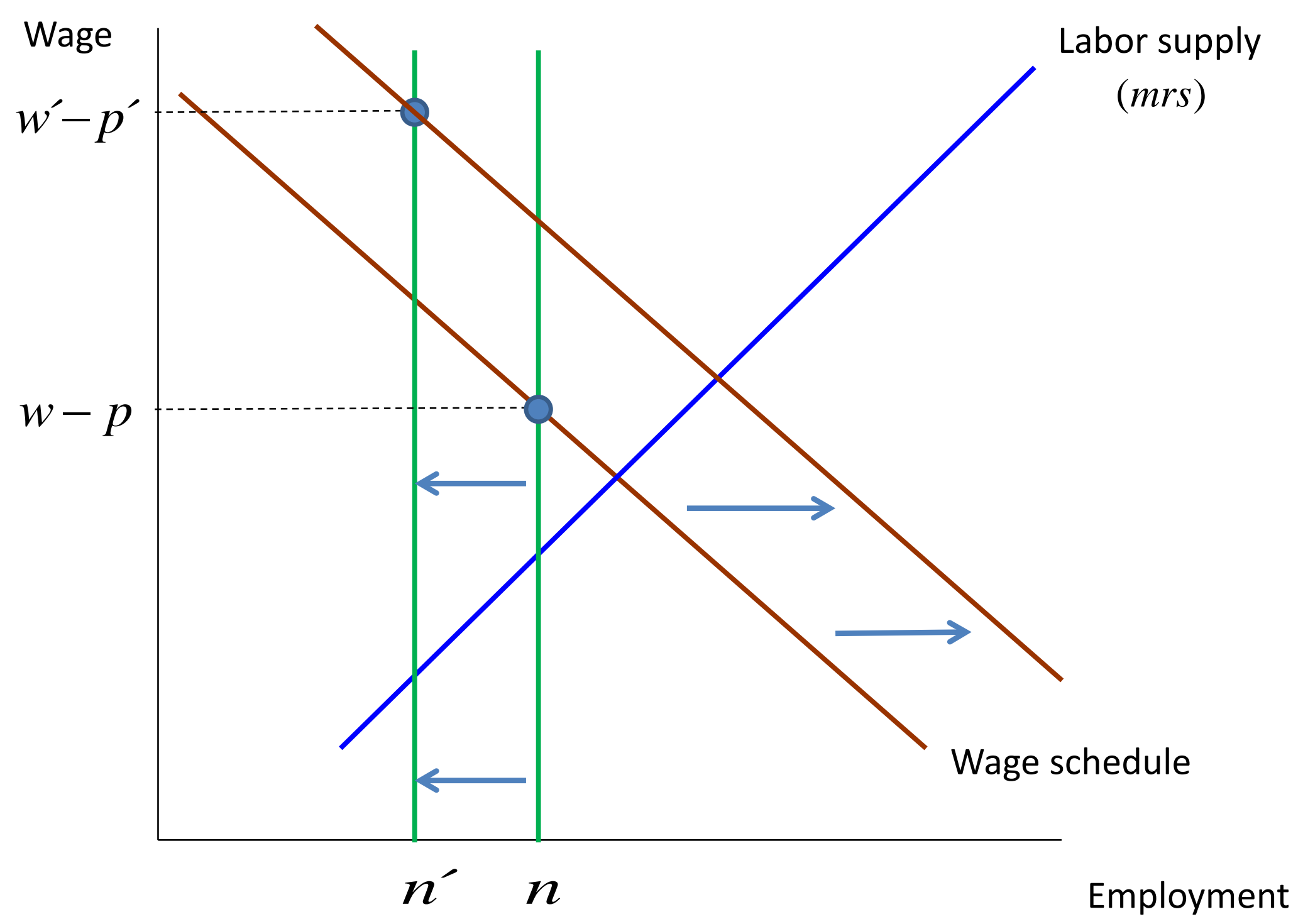


Figure 16. Dynamic Responses to a Technology Shock in the NK Model
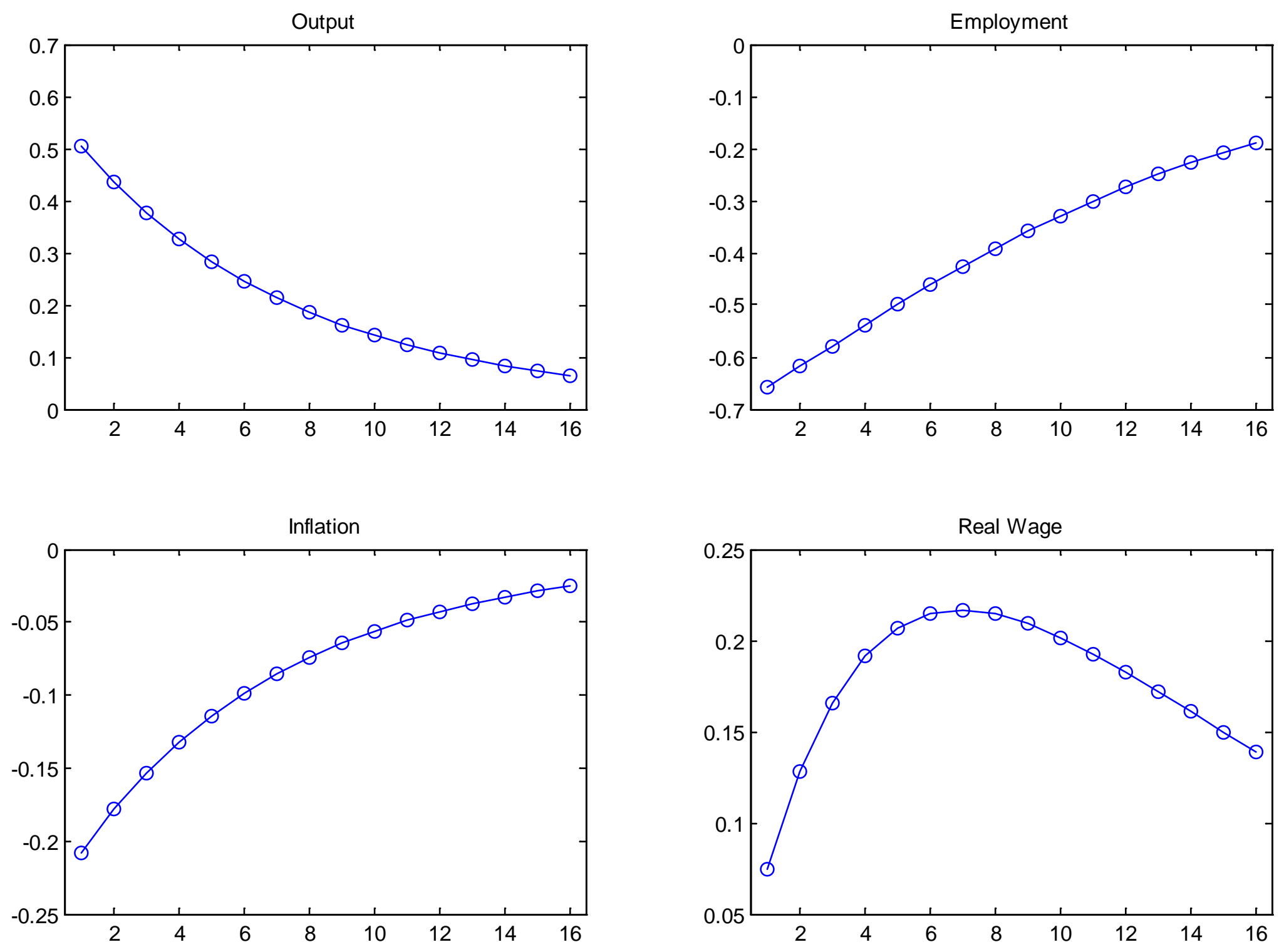
Figure 17. Dynamic Responses of Employment to a Payroll Tax Shock

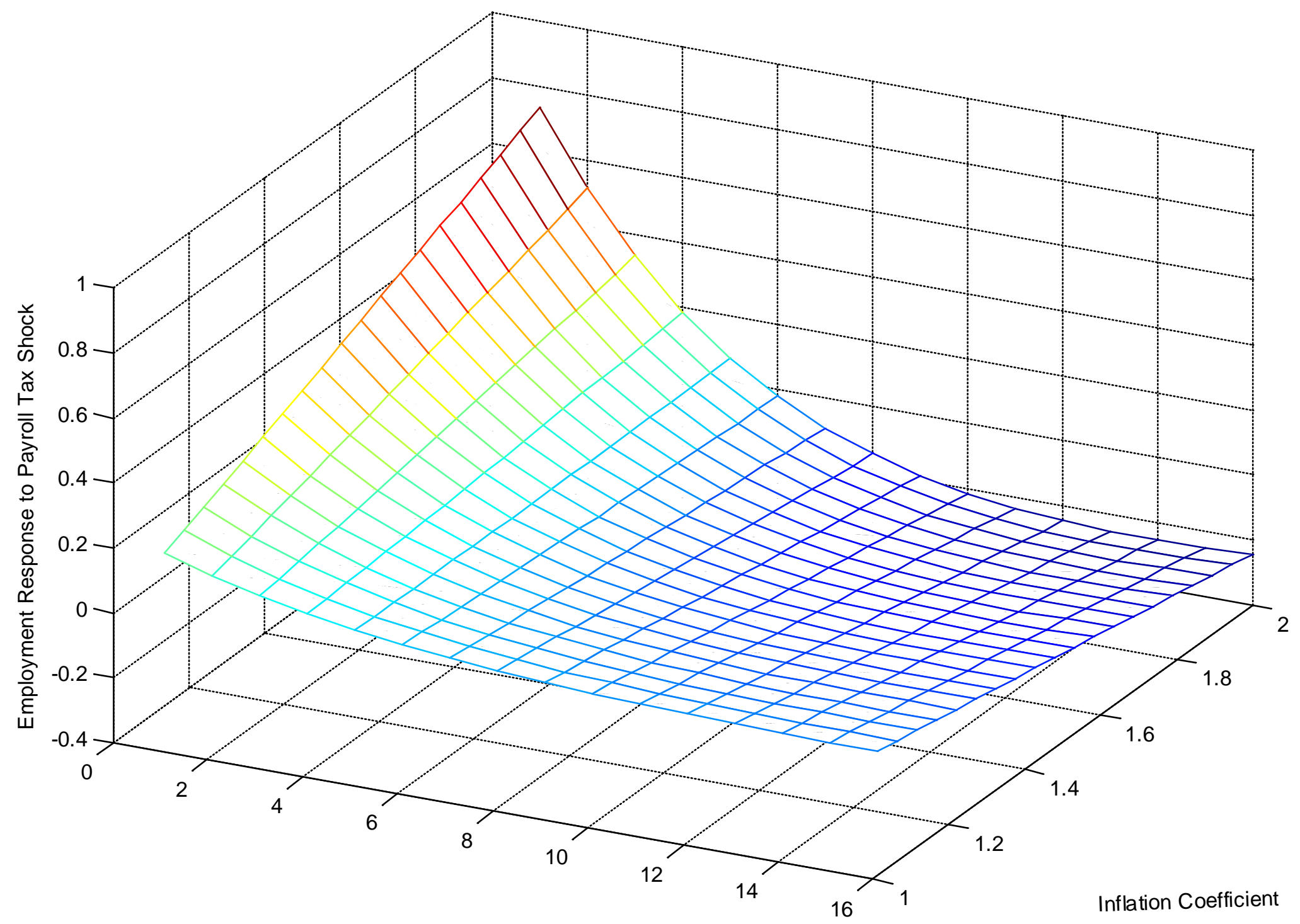




\section{Figure 18}

Wage Flexibility, Monetary Policy and Employment Volatility:

Technology Shocks

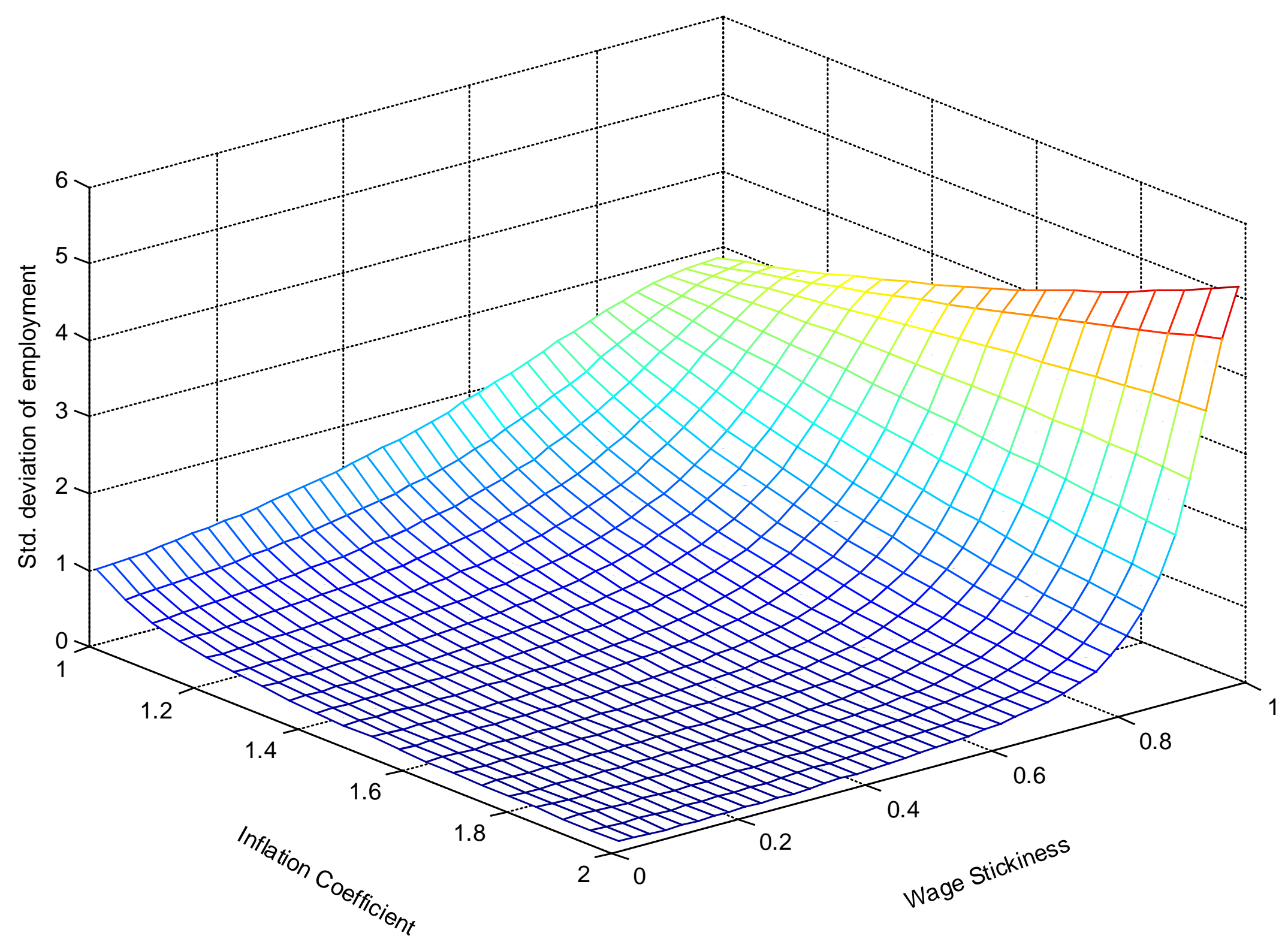




\section{Figure 19}

\section{Wage Flexibility, Monetary Policy and Welfare Technology Shocks}

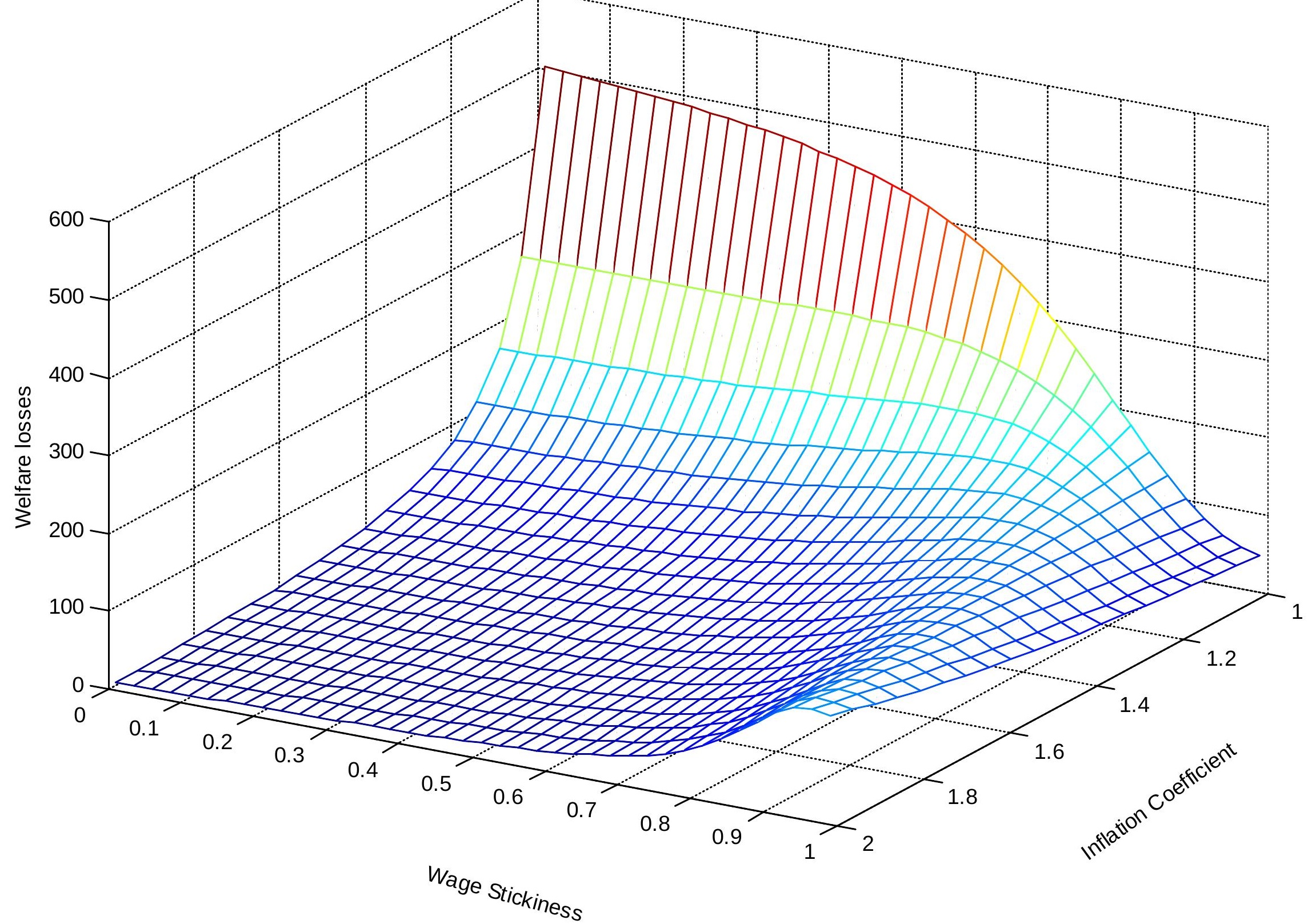




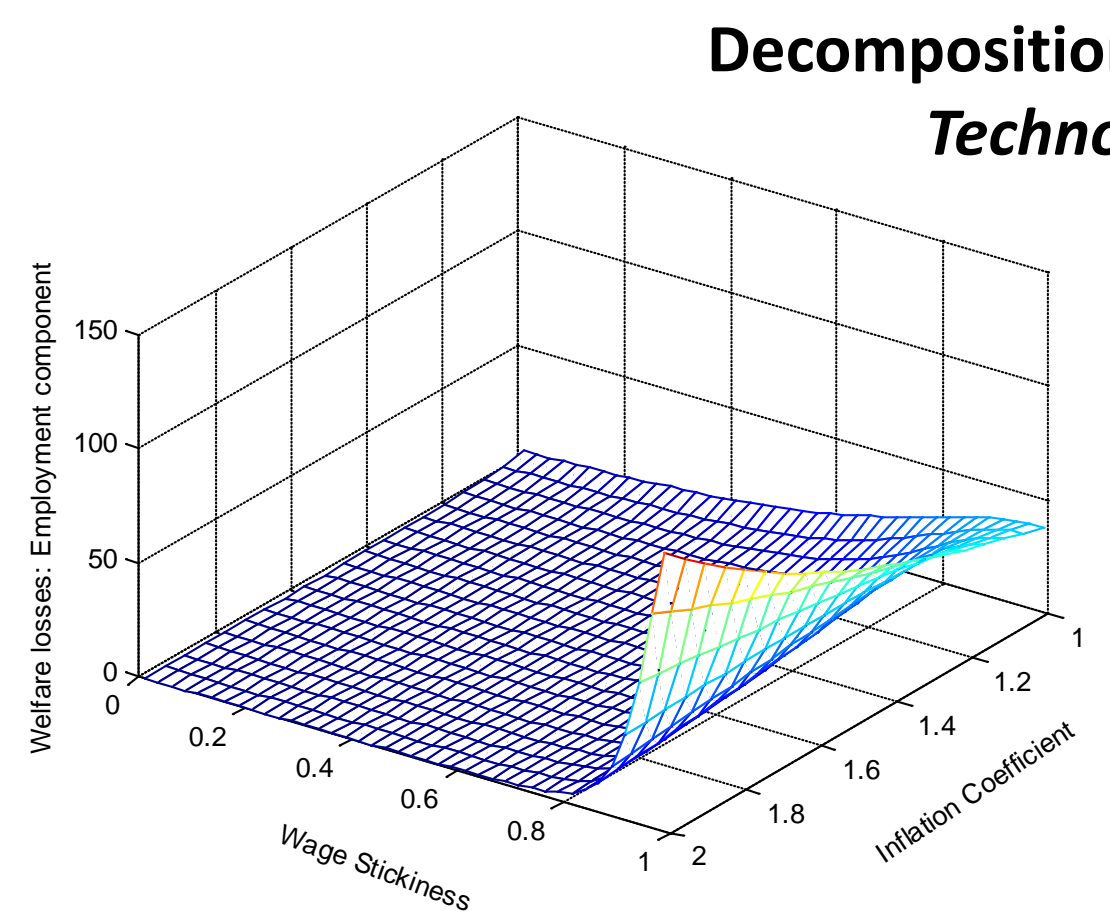

of Welfare Losses

Technology Shocks

(i) Employment
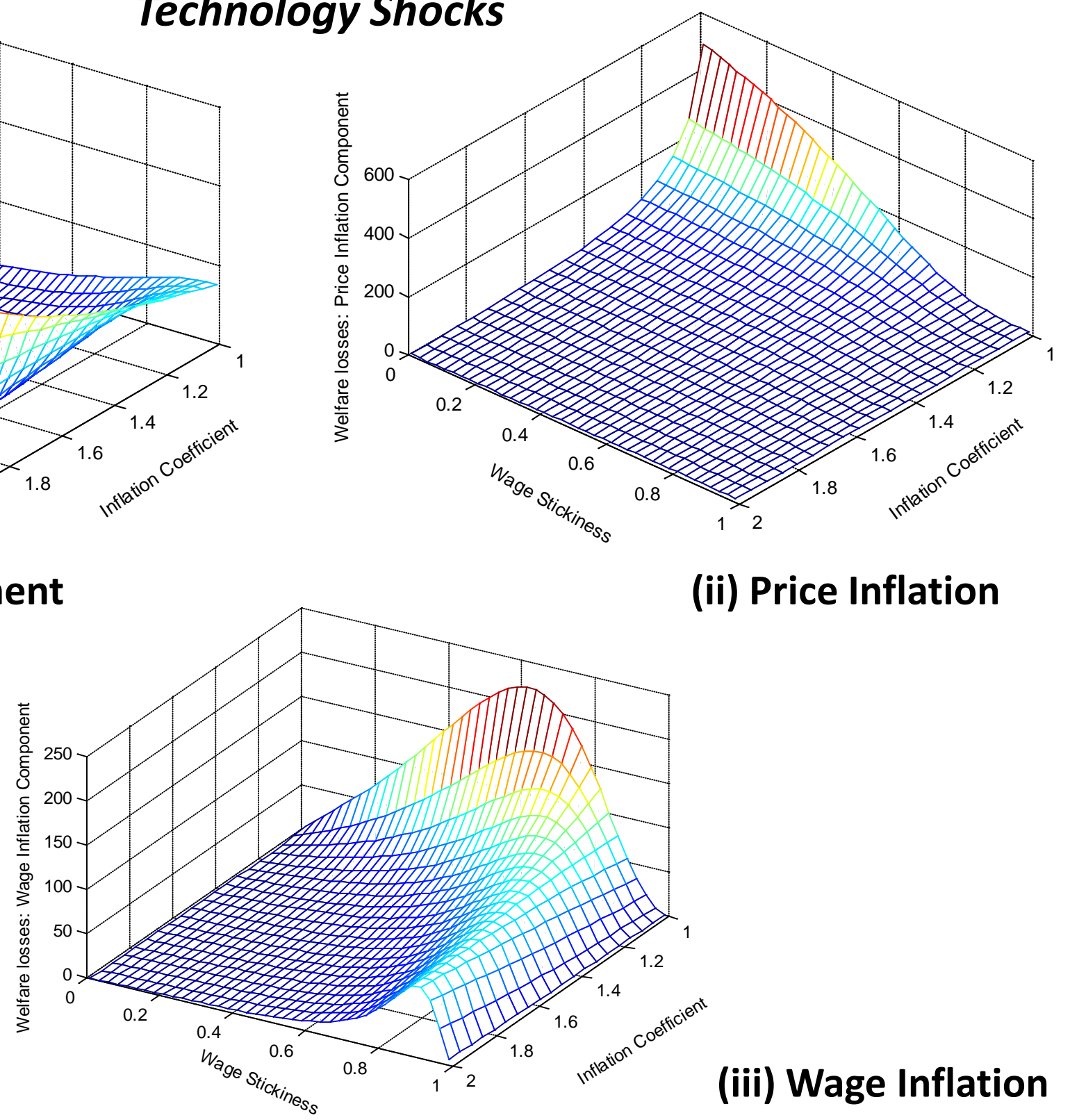

(ii) Price Inflation

(iii) Wage Inflation 


\section{Figure 21}

\section{Wage Flexibility, Monetary Policy and Employment Volatility}

Preference Shocks

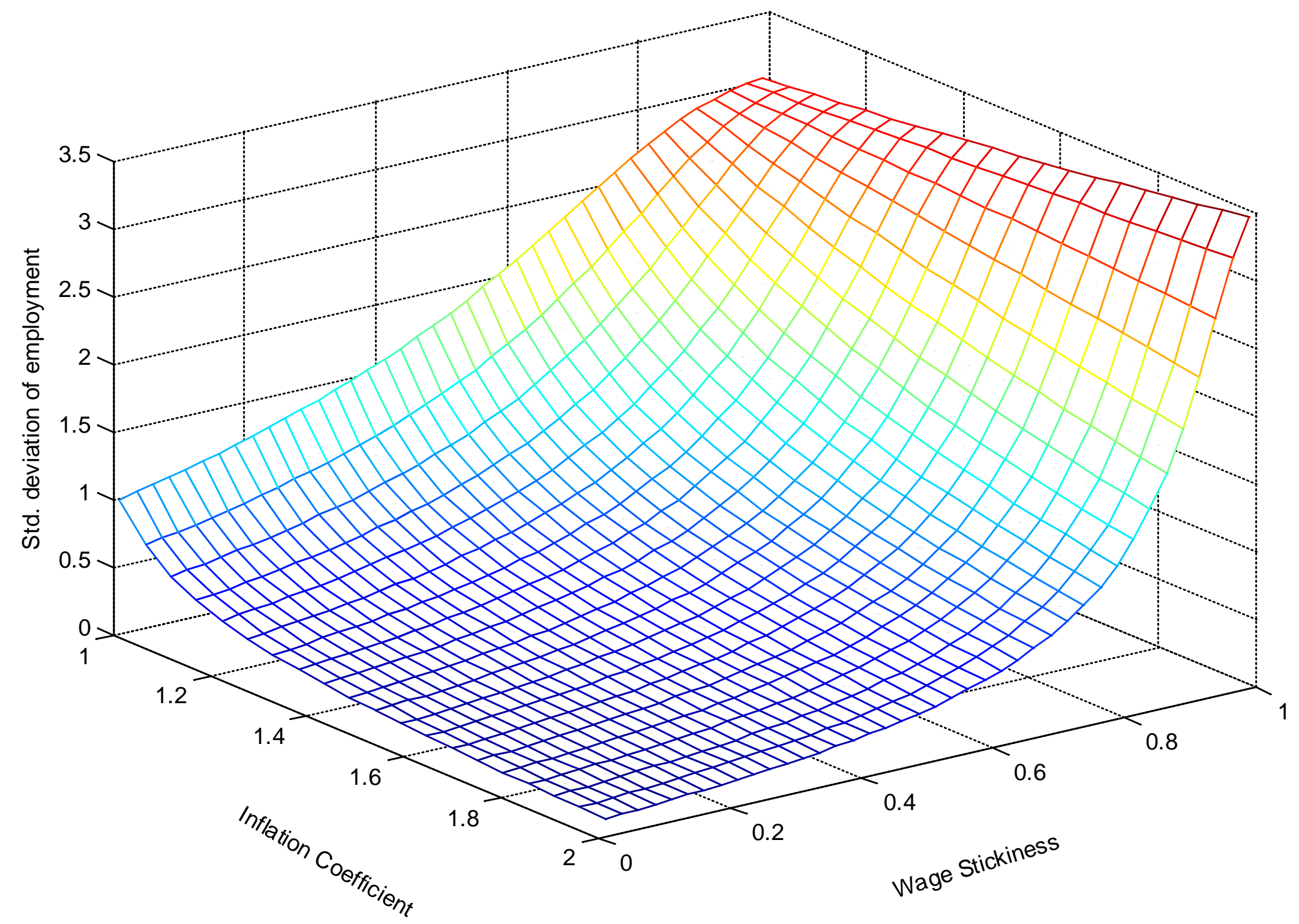


Figure 22

\section{Wage Flexibility, Monetary Policy and Welfare Preference Shocks}

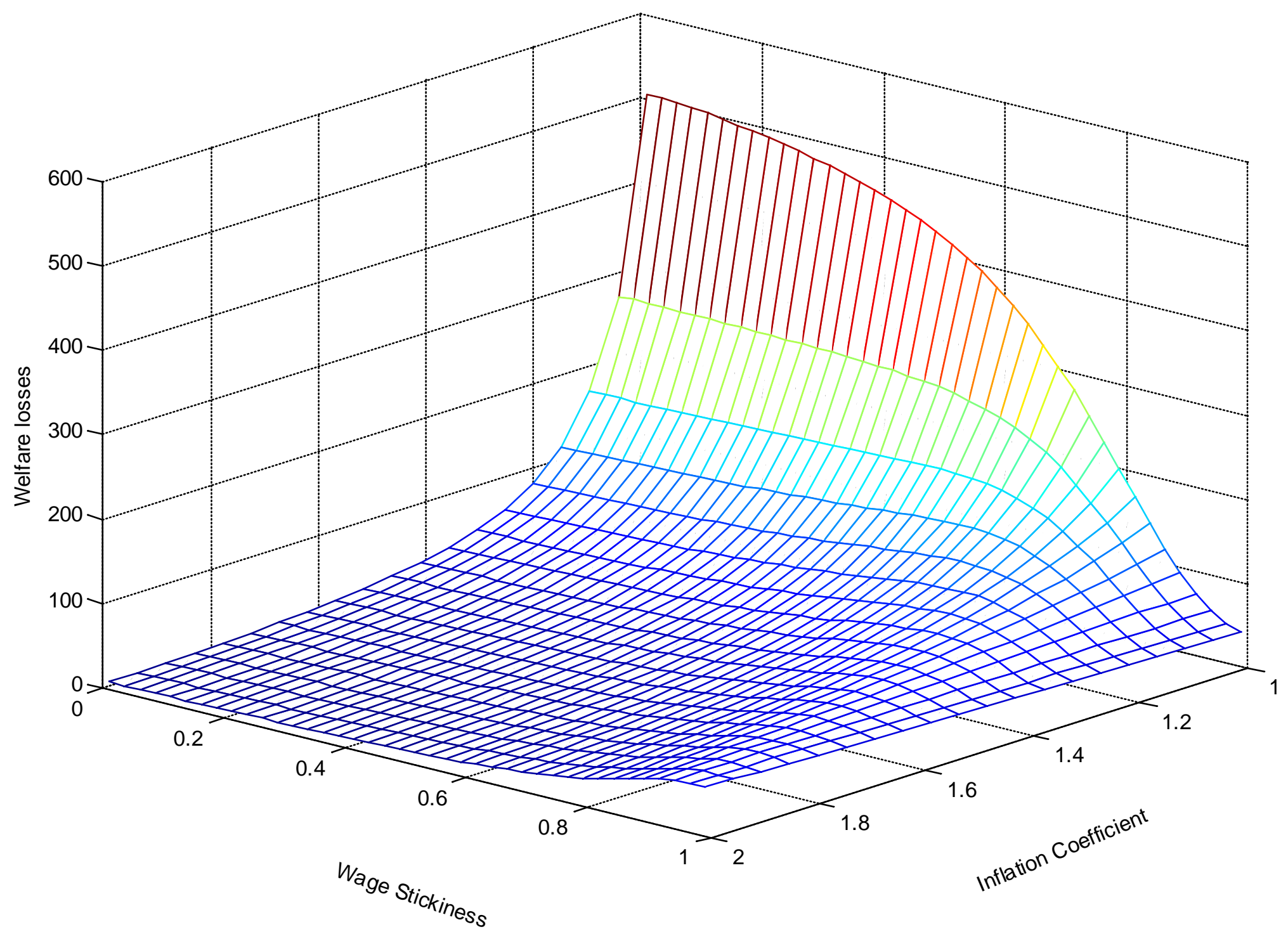


Figure 23

\section{Decomposition of Welfare Losses \\ Preference Shocks}

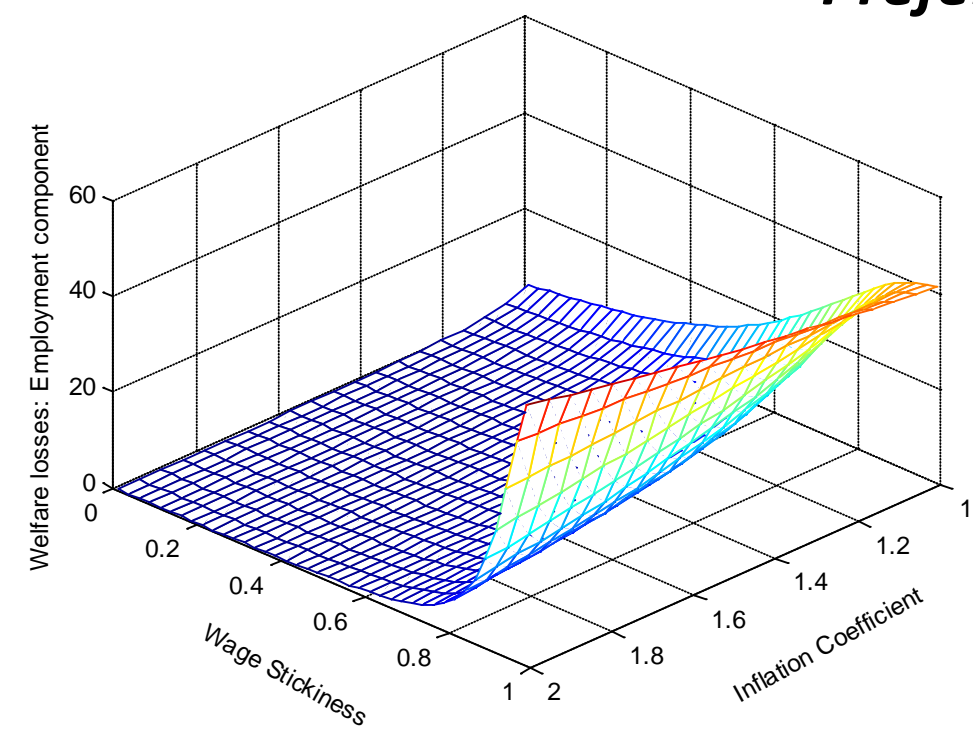

(i) Employment

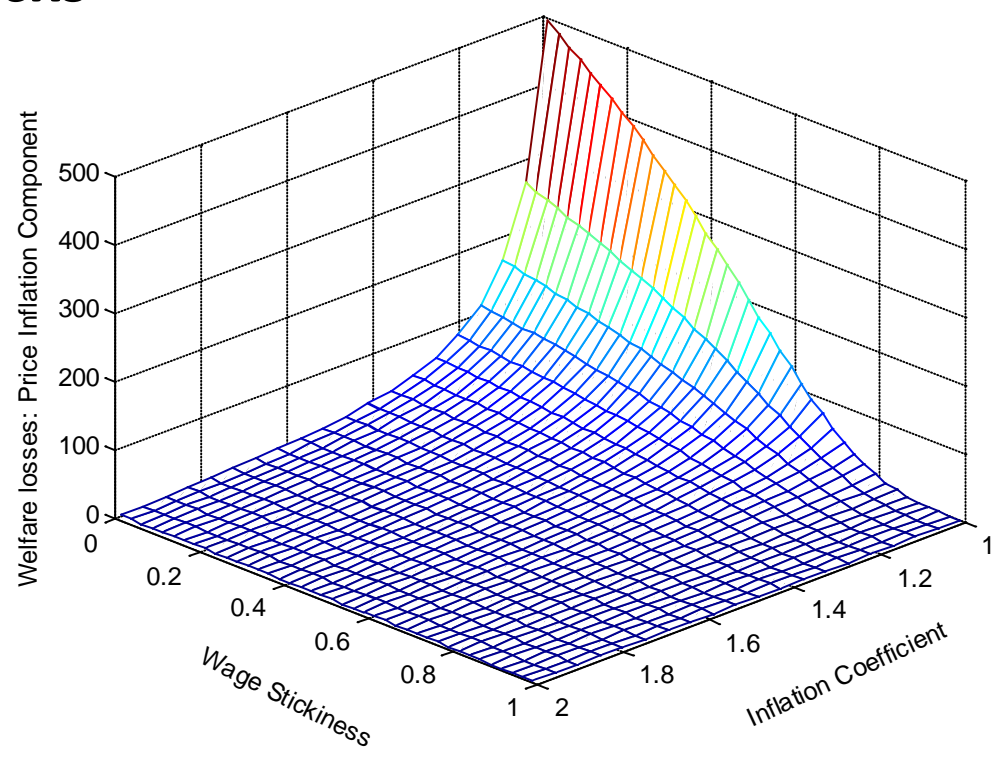

(ii) Price Inflation

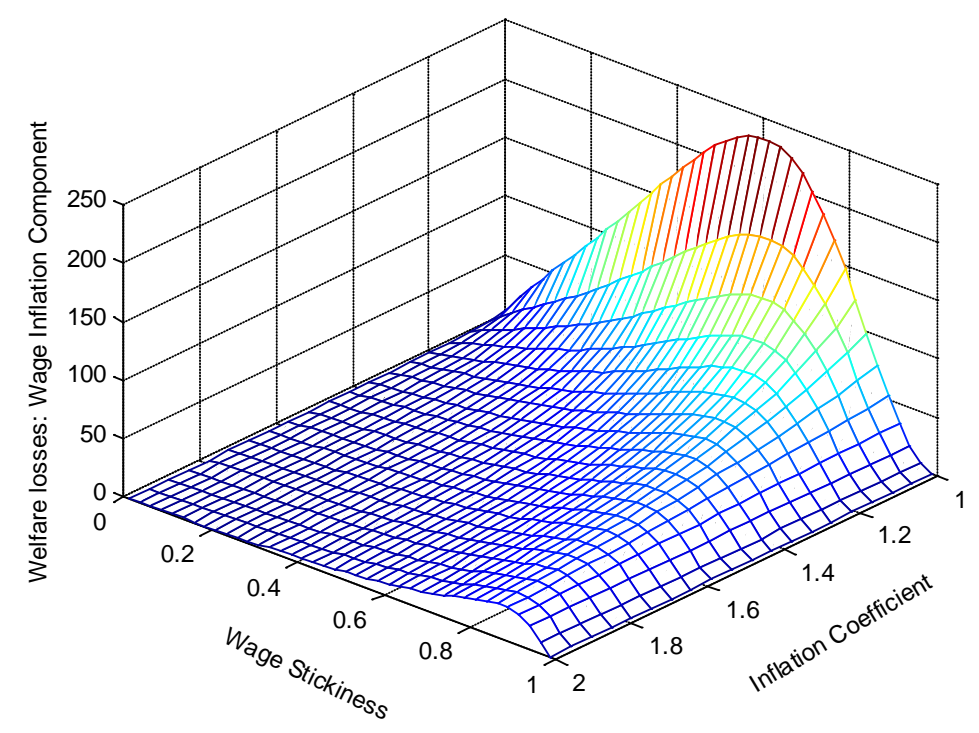

(iii) Wage Inflation 
Figure 24

Wage Flexibility and Welfare under the Optimal Monetary Policy: Baseline Calibration

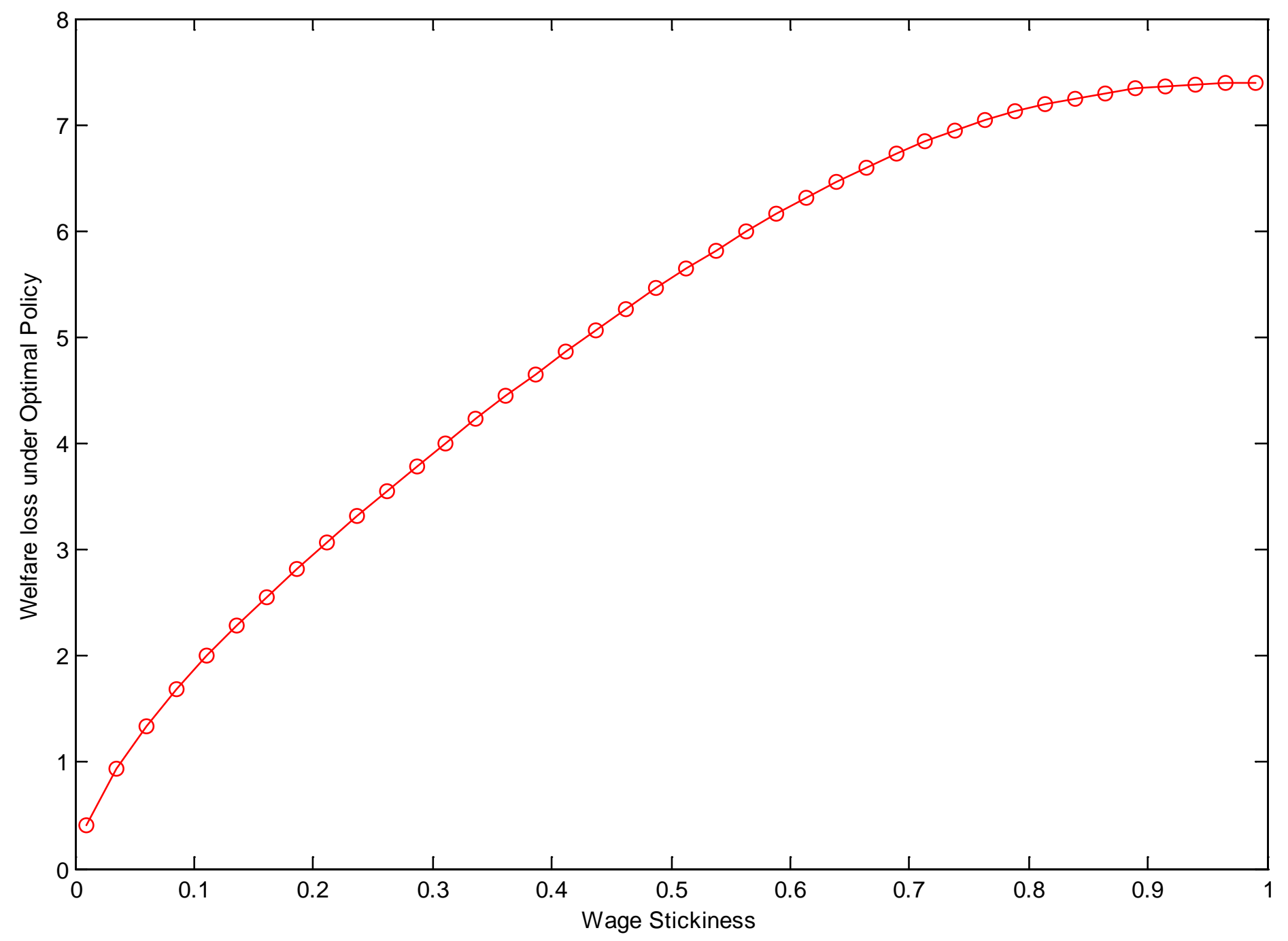


Figure 25

Decomposition of Welfare Losses under the Optimal Monetary Policy: Baseline Calibration

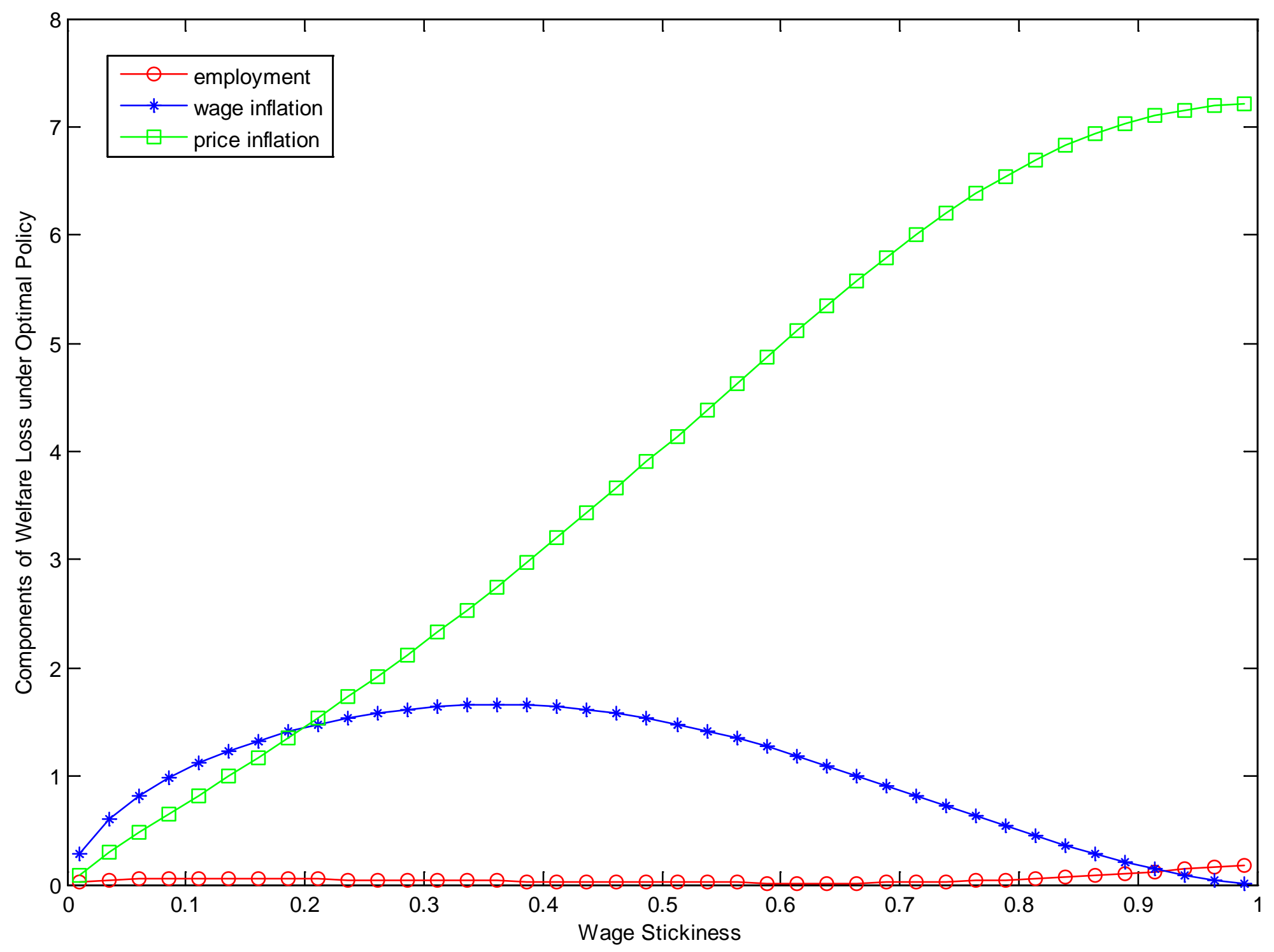


Figure 26

Wage Flexibility and Welfare under the Optimal Monetary Policy: Extreme Price Stickiness Calibration

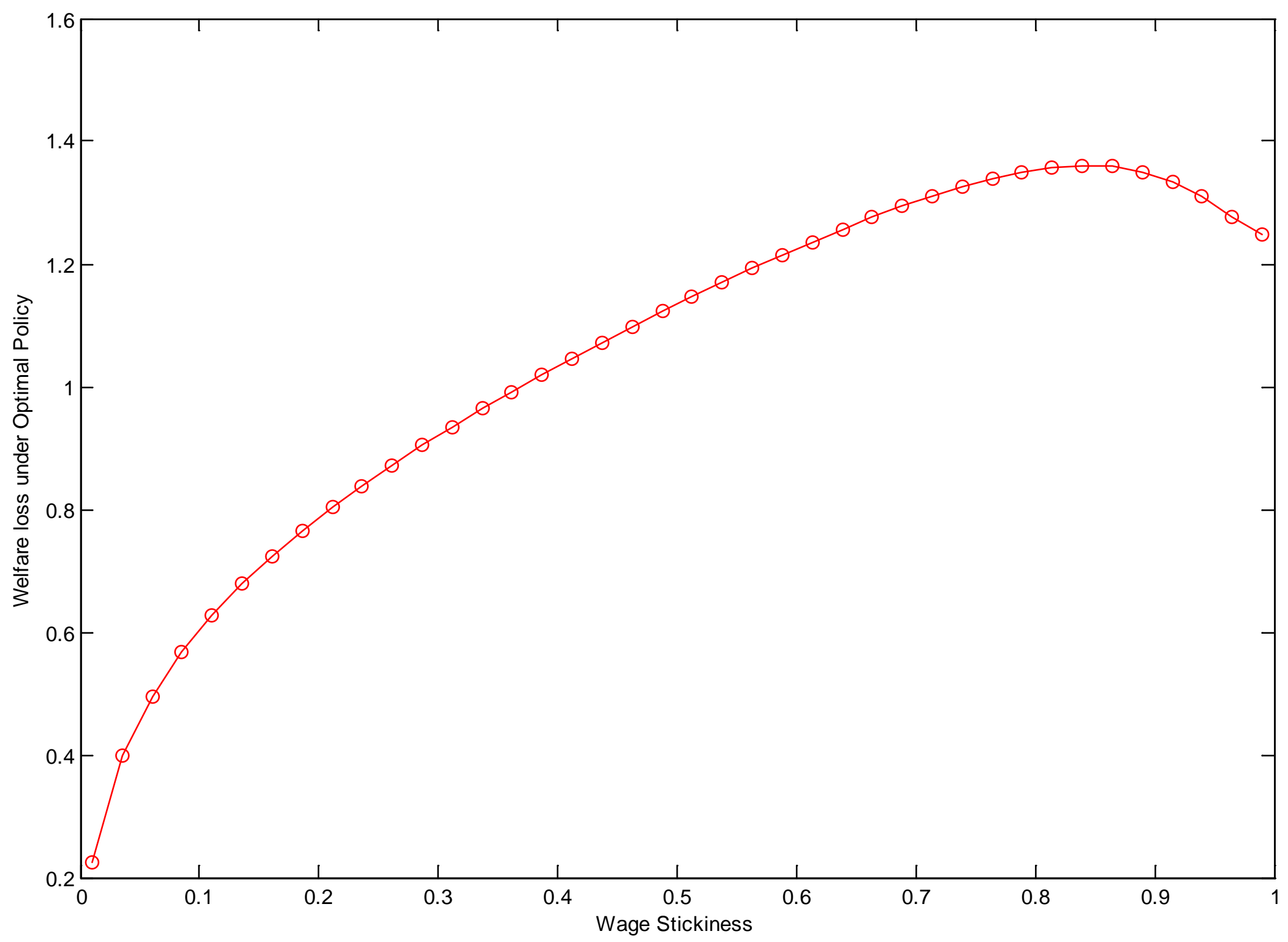


Figure 27

Decomposition of Welfare Losses under the Optimal Monetary Policy:

\section{Extreme Price Stickiness Calibration}

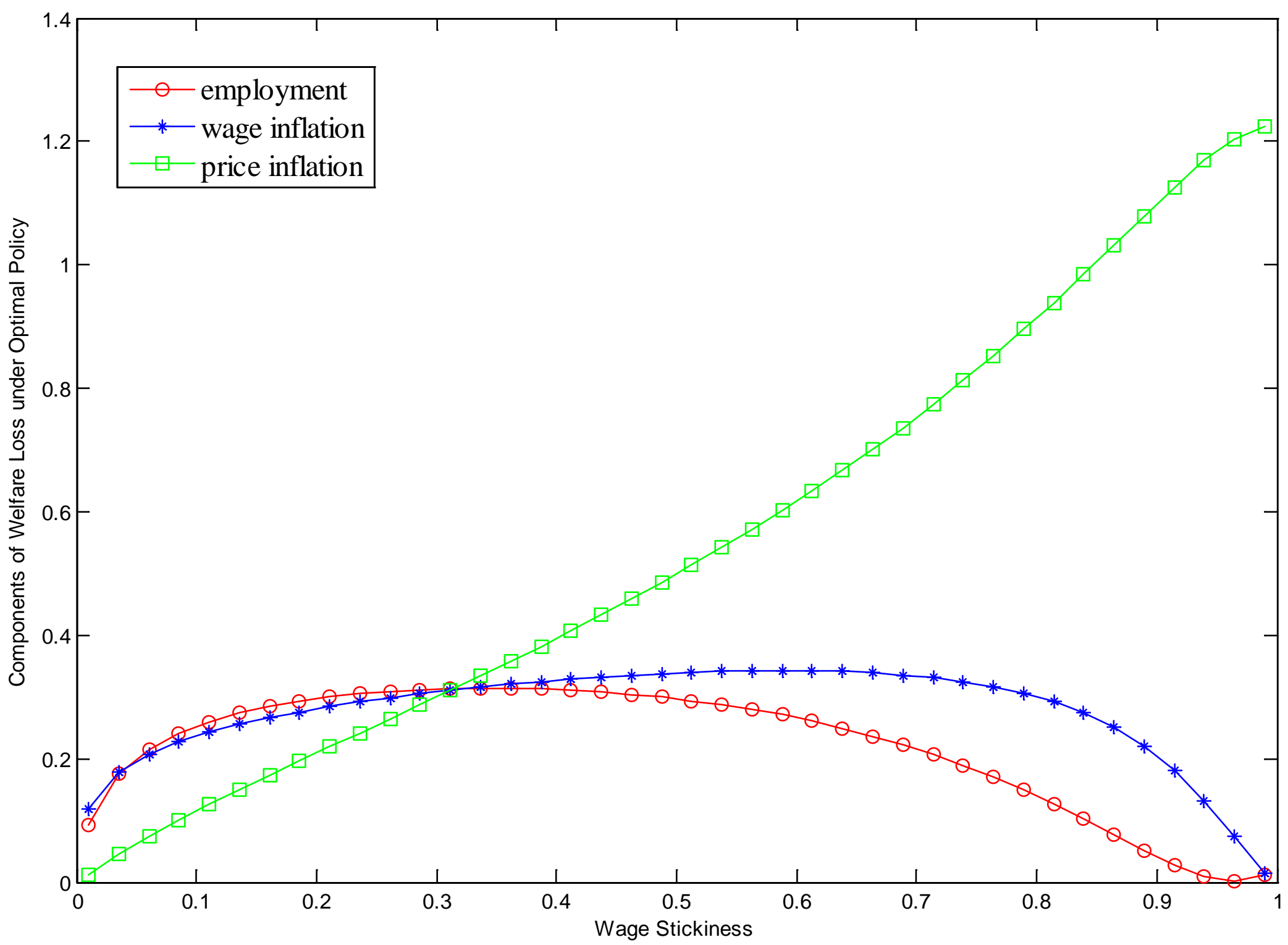

